Article

\title{
Hydrogen Production from Steam Reforming of Acetic Acid as a Model Compound of the Aqueous Fraction of Microalgae HTL Using Co-M/SBA-15 (M: $\mathrm{Cu}, \mathrm{Ag}, \mathrm{Ce}, \mathrm{Cr}$ ) Catalysts
}

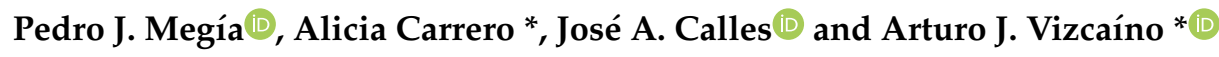 \\ Chemical and Environmental Engineering Group, Rey Juan Carlos University, c/Tulipán s/n, \\ 28933 Móstoles, Spain; pedro.megia@urjc.es (P.J.M.); joseantonio.calles@urjc.es (J.A.C.) \\ * Correspondence: alicia.carrero@urjc.es (A.C.); arturo.vizcaino@urjc.es (A.J.V.); \\ Tel.: +34-91-488-8088 (A.C.); +34-91-488-8096 (A.J.V.)
}

Received: 30 October 2019; Accepted: 28 November 2019; Published: 2 December 2019

check for updates

\begin{abstract}
Hydrogen production derived from thermochemical processing of biomass is becoming an interesting alternative to conventional routes using fossil fuels. In this sense, steam reforming of the aqueous fraction of microalgae hydrothermal liquefaction (HTL) is a promising option for renewable hydrogen production. Since the HTL aqueous fraction is a complex mixture, acetic acid has been chosen as model compound. This work studies the modification of Co/SBA-15 catalyst incorporating a second metal leading to Co-M/SBA-15 (M: Cu, Ag, Ce and $\mathrm{Cr}$ ). All catalysts were characterized by $\mathrm{N}_{2}$ physisorption, ICP-AES, XRD, TEM, $\mathrm{H}_{2}-\mathrm{TPR}, \mathrm{H}_{2}-\mathrm{TPD}$ and Raman spectroscopy. The characterization results evidenced that $\mathrm{Cu}$ and $\mathrm{Ag}$ incorporation decreased the cobalt oxides reduction temperatures, while $\mathrm{Cr}$ addition led to smaller $\mathrm{Co}^{0}$ crystallites better dispersed on the support. Catalytic tests done at $600{ }^{\circ} \mathrm{C}$, showed that Co-Cr/SBA-15 sample gave hydrogen selectivity values above $70 \mathrm{~mol} \%$ with a significant reduction in coke deposition.
\end{abstract}

Keywords: microalgae; acetic acid; steam reforming; hydrogen; cobalt; mesostructured materials

\section{Introduction}

An increase in global pollution has resulted in a search for alternative energy resources that can be substituted in place of widely used fossil fuels [1]. It is known that energy provided from hydrogen does not result in pollutant emissions when it is used in fuel cell applications [2-4]. In addition, hydrogen is extensively used in chemical and petroleum industries [5,6]. Nowadays, a hydrogen-based energy system must use renewable energy sources to be sustainable. In this sense, hydrogen production processes such as biomass gasification, and steam reforming (SR) of pyrolysis bio-oil have been widely described in the literature [7-10]. However, the use of microalgae hydrothermal liquefaction integrated with the steam reforming of the aqueous fraction is less known. Microalgae HTL requires temperatures between $250-350{ }^{\circ} \mathrm{C}$ and high pressures that can maintain the water coming from the microalgae crops in liquid state (40-250 bar). This process provides a great advantage when compared to the traditional biomass pyrolysis process, as it does not require a previous stage for biomass drying associated with high energy consumption [11-13]. Microalgae HTL products are a complex mixture of different compounds where carboxylic acids, ketones, phenols, aldehydes, fatty acids and nitrogen compounds [14] can be easily found along with a high water content. For this reason, they are not suitable for use as a fuel. However, this worthless aqueous fraction can be revalorized by hydrogen production through catalytic steam reforming $[15,16]$ but the complex composition mentioned above usually forces the use of model compounds [17-20]. Among them, acetic acid is a major component, 
which can account even for the $56 \%$ of the water-soluble products [17]. The overall equation of the acetic acid steam reforming is:

$$
\mathrm{C}_{2} \mathrm{H}_{4} \mathrm{O}_{2}+2 \mathrm{H}_{2} \mathrm{O} \rightarrow 2 \mathrm{CO}_{2}+4 \mathrm{H}_{2}
$$

Nowadays, SR catalysts are a critical point of study where activity, hydrogen selectivity and deactivation are the main concerns of the scientific community. Many papers can be found using different active phases such as $\mathrm{Ni}, \mathrm{Co}, \mathrm{Pt}$ or $\mathrm{Ru}$, with $\mathrm{Ni}$ being the most studied [21]. Hu et al. [22] studied the performance of different transition metals supported over $\mathrm{Al}_{2} \mathrm{O}_{3}$ in acetic acid steam reforming. Their study led to the conclusion that $\mathrm{Ni}$ and $\mathrm{Co}$ were more active than the other metals tested ( $\mathrm{Fe}$ and $\mathrm{Cu}$ ). They attributed this behavior to the ability for cracking not only $\mathrm{C}$-C bonds, but also C-H bonds. However, Co-based catalysts have been less reported despite the fact that they also provide high activity at moderate temperatures and also increases hydrogen yield [23,24].

Catalysts support selection is also an important point. For example, when Co was supported on $\mathrm{Al}_{2} \mathrm{O}_{3}$ or $\mathrm{TiO}_{2}$ high metal dispersion was reported but cobalt aluminates or titanates were formed avoiding the reduction of some Co species [25]. On the other hand, the interaction of Co with silica has been studied leading to the conclusion that this support does not affect to its reducibility but instead promote the sintering of cobalt particles in the calcination and reduction steps [26,27]. Apart from that, there are other advanced supports such as SBA-15, which is a mesostructured material with high surface area that may allow higher metal dispersion when compared with the amorphous silica. Furthermore, SBA-15 presents an uniform distribution of mesopores that hinders the formation of Co agglomerates preventing also catalysts deactivation due to metal sintering [28].

Co-based catalysts have shown deactivation through sintering and surface cobalt oxidation [21]. Pereira et al. [29] proposed the preparation of bimetallic catalysts to stabilize $\mathrm{Co} / \mathrm{SiO}_{2}$ catalyst to safeguard the Co particles in a reduced state during the reforming. Combining diverse metals in the same carrier has been reported as an effective way to improve the catalyst performance by facilitating the metal reducibility [30]. As reducibility promoters noble metals, transition metals or $\mathrm{CeO}_{2}$ among others can be used. Wang et al. [31] reported that $\mathrm{Cu}$ addition to $\mathrm{Ni}$ /attapulgite catalyst decreased the temperature for the reduction of nickel species. In line with this, Eschemann et al. [32] proved the efficiency of silver as a reduction promoter in $\mathrm{Co} / \mathrm{TiO}_{2}$ catalyst since $\mathrm{Co}-\mathrm{Ag}$ bonds improve the reducibility of cobalt oxides [32,33]. Besides, Harun et al. [34] achieved better $\mathrm{Ni}^{0}$ dispersion over $\mathrm{Al}_{2} \mathrm{O}_{3}$ surface when $\mathrm{Ag}$ was included in the catalyst formulation. Similarly, it was described that $\mathrm{CeO}_{2}$, presents a synergistic effect with cobalt oxides since more oxygen vacancies are formed leading to higher reducibility [35]. In addition to promoting the cobalt reducibility to avoid possible crystallites oxidation, it is necessary to obtain a small crystallite size in order to increase activity and reduce the coke formation according to its growth mechanism [36]. Accordingly, Cerdá-Moreno et al. [37] found that lower Co particle size for ethanol steam reforming led to better catalytic activity. Recently, we have found that Ni-Cr/SBA-15 showed better catalytic behavior than Ni/SBA-15 in the steam reforming of pyrolysis bio-oil aqueous fraction by decreasing $\mathrm{Ni}^{0}$ particles size [38]. Furthermore, Casanovas et al. $[39,40]$ reported that the incorporation of $\mathrm{Cr}$ to $\mathrm{Co} / \mathrm{ZnO}$ samples results in better catalytic performance when these catalysts were tested in ethanol steam reforming.

So far, we have not been able to find any references using the promoters described above in Co/SBA- 15 catalysts to be tested in acetic acid steam reforming. Therefore, the main goal of this study is the preparation of novel cobalt catalysts incorporating a second metal leading to Co-M/SBA-15 $(\mathrm{M}: \mathrm{Cu}, \mathrm{Ag}, \mathrm{Ce}$ and $\mathrm{Cr}$ ) to achieve high hydrogen production rate through acetic acid steam reforming as model compound of microalgae HTL aqueous fraction. 


\section{Results and Discussion}

\subsection{Catalysts Characterization}

Nitrogen physisorption profiles displayed in Figure 1 show type IV isotherms with a H1-type hysteresis loop according to the IUPAC classification, indicating the preservation of the initial mesoestructure of SBA-15 used as the support of these samples. Textural properties calculated from these analyses are summarized in Table 1 along with other physicochemical properties.

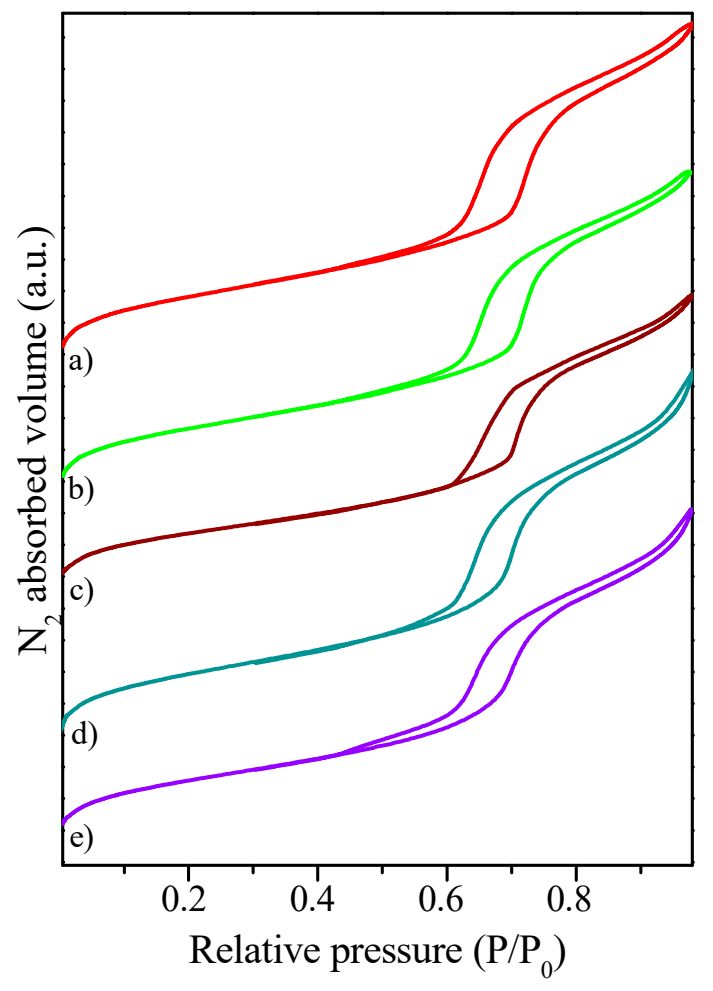

Figure 1. $\mathrm{N}_{2}$ physisorption isotherms of calcined (a) Co/SBA-15; (b) Co-Cu/SBA-15; (c) Co-Ag/SBA-15; (d) Co-Ce/SBA-15; (e) Co-Cr/SBA-15 catalysts at 77K.

Table 1. Physicochemical properties of Co-M/SBA-15 (M: Cu, Ag, Ce, Cr) catalysts.

\begin{tabular}{|c|c|c|c|c|c|c|c|}
\hline Catalyst & $\begin{array}{c}\mathrm{Co}^{\mathrm{a}} \\
(\text { wt.\%) }\end{array}$ & $\begin{array}{c}M^{\mathrm{a}} \\
(w \mathrm{t} . \%)\end{array}$ & $\begin{array}{c}S_{B E T} \\
\left(\mathrm{~m}^{2} \cdot \mathrm{g}^{-1}\right)\end{array}$ & $\begin{array}{c}D_{\text {pore }} b \\
(\mathrm{~nm})\end{array}$ & $\begin{array}{c}V_{\text {pore }}{ }^{c} \\
\left(\mathrm{~cm}^{3} \cdot \mathrm{g}^{-1}\right)\end{array}$ & $\begin{array}{c}\mathrm{D}_{\mathrm{Co}^{0}}{ }^{d} \\
(\mathrm{~nm})\end{array}$ & $\begin{array}{c}\text { Dispersion } \\
(\%)^{\text {e }}\end{array}$ \\
\hline SBA-15 & - & - & $550 \pm 3$ & $7.5 \pm 0.1$ & $0.97 \pm 0.02$ & - & - \\
\hline Co/SBA-15 & $6.4 \pm 0.1$ & - & $503 \pm 4$ & $7.2 \pm 0.1$ & $0.83 \pm 0.01$ & $9.5 \pm 0.5$ & $7.5 \pm 0.2$ \\
\hline Co-Cu/SBA-15 & $6.5 \pm 0.1$ & $2.0 \pm 0.1$ & $476 \pm 4$ & $7.2 \pm 0.1$ & $0.79 \pm 0.03$ & $9.7 \pm 0.3$ & $6.3 \pm 0.1$ \\
\hline Co-Ag/SBA-15 & $6.4 \pm 0.1$ & $1.6 \pm 0.1$ & $419 \pm 4$ & $6.9 \pm 0.1$ & $0.71 \pm 0.01$ & $12.3 \pm 0.4$ & $3.9 \pm 0.6$ \\
\hline Co-Ce/SBA-15 & $6.6 \pm 0.1$ & $1.7 \pm 0.1$ & $494 \pm 1$ & $7.4 \pm 0.1$ & $0.84 \pm 0.01$ & $9.6 \pm 0.2$ & $6.5 \pm 0.1$ \\
\hline Co-Cr/SBA-15 & $6.8 \pm 0.1$ & $1.8 \pm 0.1$ & $469 \pm 1$ & $7.1 \pm 0.1$ & $0.81 \pm 0.02$ & $7.2 \pm 0.1$ & $9.9 \pm 0.3$ \\
\hline
\end{tabular}

${ }^{a}$ Determined by ICP-AES (M: $\mathrm{Cu}, \mathrm{Ag}, \mathrm{Ce}$ or $\mathrm{Cr}$ ) in reduced samples, ${ }^{\mathrm{b}} \mathrm{BJH}$ desorption average pore diameter,

${ }^{c}$ Measured at $\mathrm{P} / \mathrm{P}_{0}=0.97,{ }^{\mathrm{d}}$ Determined from XRD of reduced catalysts by Scherrer equation from the (111)

diffraction plane of $\mathrm{Co}^{0},{ }^{\text {e }}$ Determined from $\mathrm{H}_{2}$-TPD results using formula from $\mathrm{Li}$ et al. [41] assuming $\mathrm{H} / \mathrm{Co}=1$.

The metals loading is close to the nominal value used during the catalysts preparation. Metal addition to bare SBA-15 leads to a decrease in BET surface area with Co-Ag/SBA-15 being the sample with the smallest pore size, pore volume and surface area. This phenomena has been described previously [42] and was ascribed to Ag structures growing in the mesopores of SBA-15. Similar textural properties were found in $\mathrm{Co}-(\mathrm{Cu}, \mathrm{Ce}$ or $\mathrm{Cr}) / \mathrm{SBA}-15$ samples.

Figure 2 shows the XRD patterns of the calcined samples. Peaks corresponding to cubic $\mathrm{Co}_{3} \mathrm{O}_{4}$ appear in all samples (JCDPS 01-071-4921). Attending to Co-Cu/SBA-15 sample, a small peak at 
$38.3^{\circ}$ can be observed due to the formation of monoclinic CuO (JCDPS 01-089-2531). In case of Co-Ce/SBA-15, two small peaks over $28.5^{\circ}$ and $47.5^{\circ}$ can be seen due to the presence of cubic $\mathrm{CeO}_{2}$ (JCDPS 01-089-8436). Ag and Cr oxides were not detected by XRD due to the overlap of the main diffraction peaks of cubic $\mathrm{Ag}_{2} \mathrm{O}$ (JCPDS 00-012-0793), rhombohedral $\mathrm{Cr}_{2} \mathrm{O}_{3}$ (JCPDS 00-002-1362) and cubic $\mathrm{CoCr}_{2} \mathrm{O}_{4}$ spinel (JCPDS 00-022-1084), with the $\mathrm{Co}_{3} \mathrm{O}_{4}$ pattern. The higher Co content compared to $\mathrm{Ag}$ and $\mathrm{Cr}$ also contributes to the non-detection of $\mathrm{Ag}$ and $\mathrm{Cr}$ oxides by XRD as were observed in previous works $[43,44]$. XRD patterns corresponding to $\mathrm{Co}-(\mathrm{Cu}, \mathrm{Ag}$ or $\mathrm{Ce}) / \mathrm{SBA}-15$ present narrower $\mathrm{Co}_{3} \mathrm{O}_{4}$ peaks and slightly larger $\mathrm{Co}_{3} \mathrm{O}_{4}$ crystallites were obtained comparing when compared to Co/SBA-15 sample.

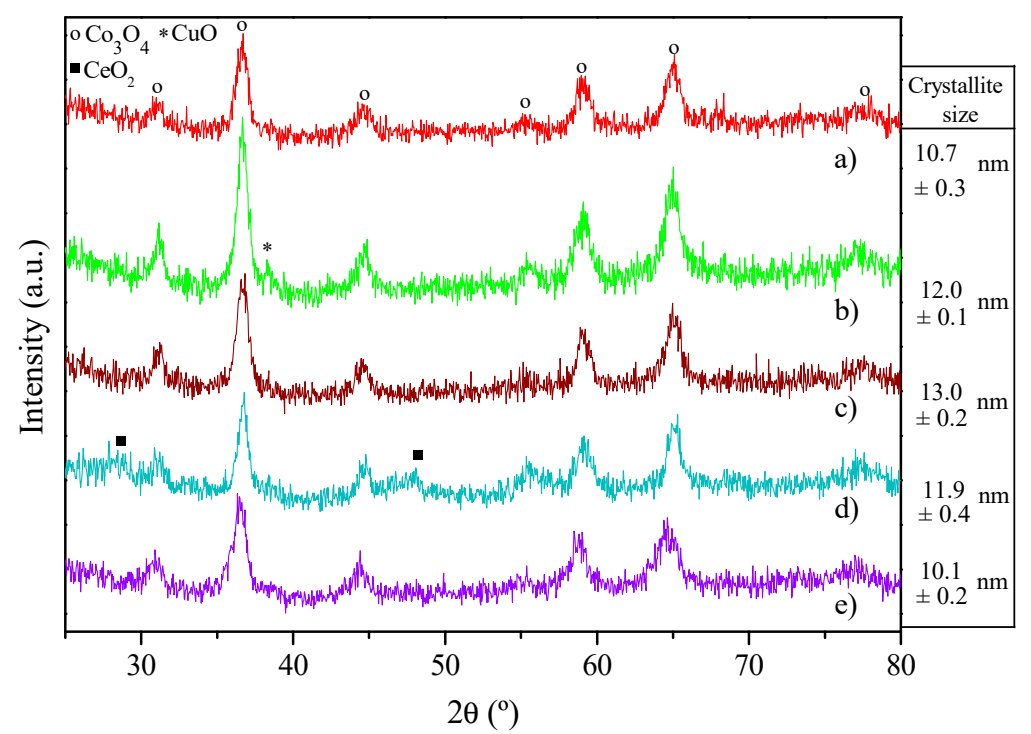

Figure 2. XRD of calcined (a) Co/SBA-15; (b) Co-Cu/SBA-15; (c) Co-Ag/SBA-15; (d) Co-Ce/SBA-15; (e) $\mathrm{Co}-\mathrm{Cr} / \mathrm{SBA}-15$ catalysts. $\mathrm{Co}_{3} \mathrm{O}_{4}$ crystallites sizes calculated from the (311) diffraction plane using Scherrer equation are displayed on the right.

Figure 3 shows the TEM micrographs of calcined samples. Irregular metal oxides particles can be observed, some of them formed in the channels of SBA-15, while other particles were formed over the external surface as previously reported [43]. The presence of $\mathrm{Co}$ and promoters $(\mathrm{Cu}, \mathrm{Ag}, \mathrm{Ce}$ or $\mathrm{Cr}$ ) were evaluated in the corresponding sample by EDX indicating an intimate contact between $\mathrm{Co}$ oxide and promoters. Co-Ag/SBA- 15 catalyst has large metallic nanostructures through the SBA-15 channels and $\mathrm{Ag}_{2} \mathrm{O}$ particles can be also observed over the support [45]. The incorporation of high Ag loadings ( $>1 \mathrm{wt}$. \%) affects support structure and distribution of $\mathrm{Ag}_{2} \mathrm{O}$ particles over the catalyst because the probability of Ag-Ag bond formation increases [32,33]. On the other side, it is noticeable how Co-Cr/SBA-15 sample clearly shows the highest dispersion over the support with very small metal oxide particles, which is in agreement with the lower metal diameter calculated from XRD (Table 1).

Figure 4 displays the $\mathrm{H}_{2}$-TPR profiles of the calcined catalysts. In the case of Co/SBA- 15 sample, the reduction profile shows two main reduction stages. The first one with maxima found at $248-267^{\circ} \mathrm{C}$ and a shoulder around $332{ }^{\circ} \mathrm{C}$. These peaks are attributed to the reduction of $\mathrm{Co}_{3} \mathrm{O}_{4}$ to $\mathrm{CoO}$ and subsequently to $\mathrm{Co}^{0}$. The reduction stage at high temperature, with a maximum placed at $494{ }^{\circ} \mathrm{C}$, can be attributed to the presence of Co-oxide species with stronger interaction with the support [46]. $\mathrm{Cu}$ addition led to a clear decrease of the reduction temperature as observed in $\mathrm{Co}-\mathrm{Cu} / \mathrm{SBA}-15$ profile. 


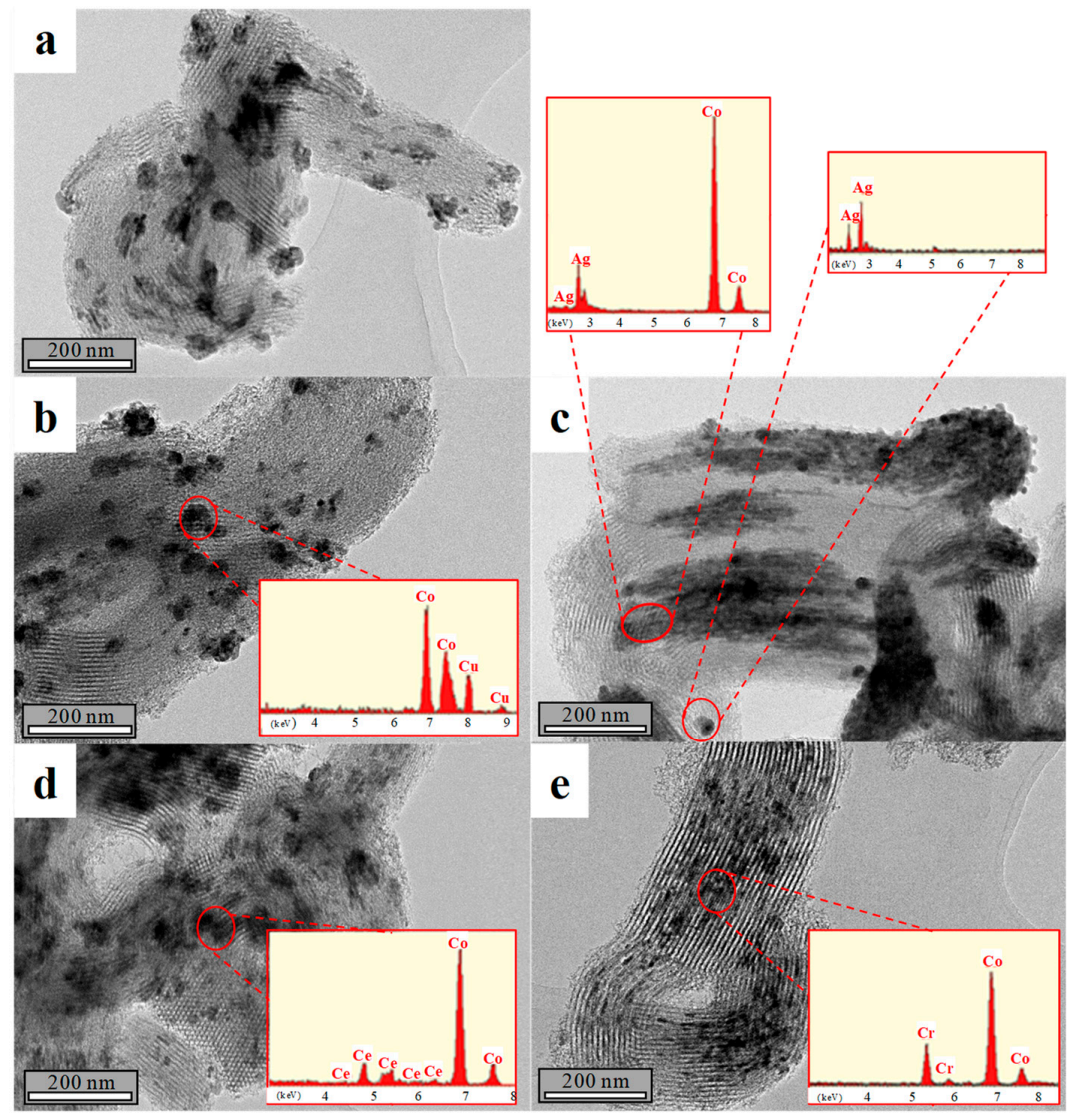

Figure 3. TEM micrographs of calcined samples (a): Co/SBA-15; (b): Co-Cu/SBA-15; (c): Co-Ag/SBA-15; (d): Co-Ce/SBA-15; (e): Co-Cr/SBA-15.

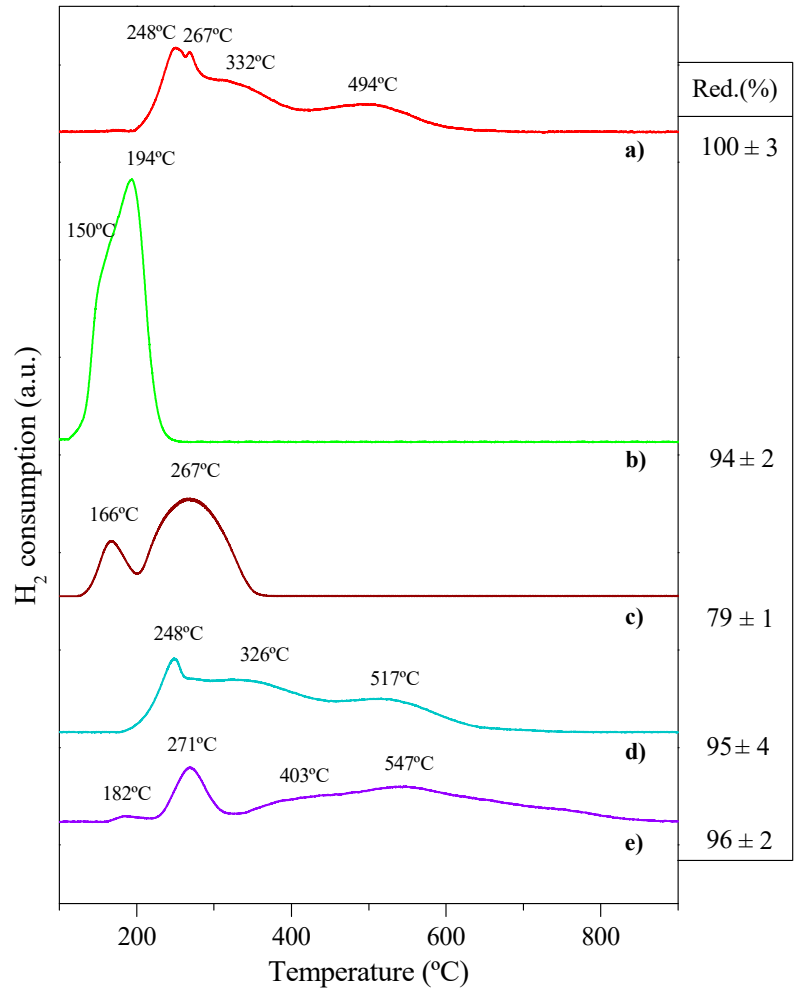

Figure 4. $\mathrm{H}_{2}$-TPR profiles for (a) Co/SBA-15; (b) Co-Cu/SBA-15; (c) Co-Ag/SBA-15; (d) Co-Ce/SBA-15; (e) Co-Cr/SBA-15 samples. Red. (\%) data displayed on the right correspond to reducibility. 
The reduction zone is located at temperatures between $140-260{ }^{\circ} \mathrm{C}$ with two maxima at 150 and $194{ }^{\circ} \mathrm{C}$. Whereas the lower temperature peak is ascribed to the simultaneous reduction of $\mathrm{CuO}$ and $\mathrm{Co}_{3} \mathrm{O}_{4}$ to $\mathrm{Cu}^{0}$ and $\mathrm{CoO}$ respectively, the other one is related to the reduction of $\mathrm{CoO}$ to $\mathrm{Co}^{0}$ [47]. This effect of $\mathrm{Cu}$ in lowering reduction temperature of metal oxides was observed in previous works for Ni-based catalysts [43]. Co-Ag/SBA-15 catalyst showed two clearly different reduction areas, also at low temperature. While the zone over $267^{\circ} \mathrm{C}$ is related to the Co oxides next to $\mathrm{Ag}$, the other one around $166^{\circ} \mathrm{C}$ is attributed to the reduction of segregated $\mathrm{Ag}_{2} \mathrm{O}$ particles to $\mathrm{Ag}^{0}$ [48]. On the other hand, Co-Ce/SBA-15 sample showed a reduction profile similar to Co/SBA-15 with the peak at $494^{\circ} \mathrm{C}$ shifted to higher reduction temperature due to an emerging peak assigned to superficial cerium oxide [49]. Finally, in the reduction profile of Co-Cr/SBA- 15 had a new peak around $182{ }^{\circ} \mathrm{C}$, probably due to the reduction of Cr-oxides to $\mathrm{Cr}^{3+}$ which can be affected by the presence of $\mathrm{Co}_{3} \mathrm{O}_{4}$ [50] although it could not be detected by XRD. The peak attributed to $\mathrm{Co}_{3} \mathrm{O}_{4}$ reduction at $271{ }^{\circ} \mathrm{C}$ remained unaltered whereas the peak of $\mathrm{CoO}$ reduction shifts to higher temperatures due to the presence of $\mathrm{Cr}$ species [51] or to the confinement of Co oxides into SBA-15 channels because of their smaller size. Based on the literature, the most likely option is the formation of a cobalt chromate mixed oxide [52], although none could be detected by XRD due to the overlap of the main diffraction lines of $\mathrm{CoCr}_{2} \mathrm{O}_{4}$ with those of $\mathrm{Co}_{3} \mathrm{O}_{4}$. The XRD patterns of the samples after reduction at $700{ }^{\circ} \mathrm{C}$ under pure $\mathrm{H}_{2}$ flow are displayed in Figure 5. No peaks ascribed to $\mathrm{Co}_{3} \mathrm{O}_{4}$ pattern can be detected whereas cubic Co ${ }^{0}$ (JCDPS 00-001-1259) peaks corresponding to (111), (200) and (220) planes showing the reflection at $2 \theta=44.4^{\circ}, 51.3^{\circ}$ and $75.4^{\circ}$ can be observed in all samples after the reduction process.

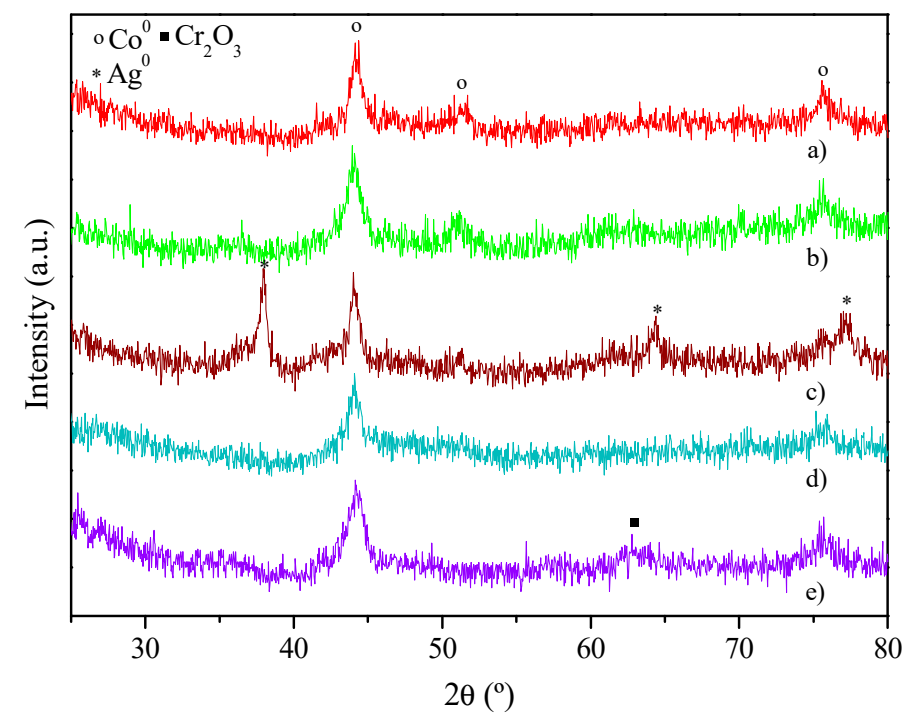

Figure 5. XRD of reduced (a) Co/SBA-15; (b) Co-Cu/SBA-15; (c) Co-Ag/SBA-15; (d) Co-Ce/SBA-15; (e) Co-Cr/SBA- 15 catalysts at $700{ }^{\circ} \mathrm{C}$.

Cubic $\mathrm{Ag}^{0}$ (JCDPS 00-043-1038) diffraction peaks arose in the Co-Ag/SBA-15 sample at $2 \theta=38.1^{\circ}$, $64.5^{\circ}$ and $77^{\circ}$, ascribed to (111), (200) and (220) reflection planes, respectively. In this case, some Co-oxides could remain in this sample explaining its low reducibility (see Figure 4) but they were not detected because there is an overlapping between $\mathrm{Ag}^{0}$ and $\mathrm{Co}_{3} \mathrm{O}_{4}$ patterns at $38.1^{\circ}$ and $64.5^{\circ}$. In Co-Cr/SBA- 15 catalyst a peak placed at $2 \theta=63.7^{\circ}$ was assigned to rhombohedral $\mathrm{Cr}_{2} \mathrm{O}_{3}$ (JCDPS 00-002-1362) probably coming from the release of $\mathrm{CoO}$ from the spinel $\mathrm{CoCr}_{2} \mathrm{O}_{4}$. No diffraction peaks of cubic $\mathrm{Cu}^{0}$ (JCPDS 00-001-1241) were distinguished in Co-Cu/SBA-15 sample due to the overlapping between $\mathrm{Cu}^{0}$ and $\mathrm{Co}^{0}$ diffraction peaks. Co-Ce/SBA-15 reduced sample showed only the diffraction peak of metallic $\mathrm{Co}$. The absence of $\mathrm{CeO}_{2}$ diffraction peaks prompted us to think about the formation of a non-stoichiometric $\mathrm{CeO}_{2-\sigma}$ that cannot be detected by XRD [53]. 
$\mathrm{Co}^{0}$ crystallite sizes were calculated by the Scherrer equation from the diffraction plane (111). In general, whereas Co-Cu/SBA-15 and Co-Ce/SBA-15 samples present a crystallite size similar to Co/SBA-15, Co-Ag/SBA-15 had the largest crystallites (see Table 1) which differs from the literature as silver loading in $\mathrm{Co}-\mathrm{Ag} / \mathrm{SBA}-15$ is higher than in references [31,32]. In contrast, $\mathrm{Co}-\mathrm{Cr} / \mathrm{SBA}-15$ presented the lowest Co crystallite size because making a parallelism with the paper of Amin et al. [54] $\mathrm{Cr}$-oxides can suppress the extension growth of $\mathrm{Cu}$-oxides in that case, Co-oxides in our case.

$\mathrm{H}_{2}$-TPD analysis was carried out in order to measure the dispersion of the metallic phase over the support. The results, summarized in Table 1 , follow the opposite trend as $\mathrm{Co}^{0}$ crystallite sizes calculated from the Scherrer equation. Co-Cr/SBA-15 sample reached the highest active phase dispersion over the support. This effect can be clearly observed in Figure 6, where $\mathrm{Co}^{0}$ crystallite sizes are displayed against dispersion and it is clear that the only promoter that improves the base Co/SBA- 15 catalyst is $\mathrm{Cr}$. In addition, other authors have reported smaller crystallite size when $\mathrm{Cr}$ was incorporated to the catalyst formulation suggesting the capacity of $\mathrm{Cr}_{2} \mathrm{O}_{3}$ to act as a textural promoter preventing metallic sintering [55-57]. It should be noted that in a previous work we reported the same behavior with $\mathrm{Ni}-\mathrm{Cr} / \mathrm{SBA}-15$ sample $[38,43]$, in line with the results obtained by $\mathrm{Xu}$ et al. during the co-impregnation of $\mathrm{Cr}$ and Ni over char as support [58].

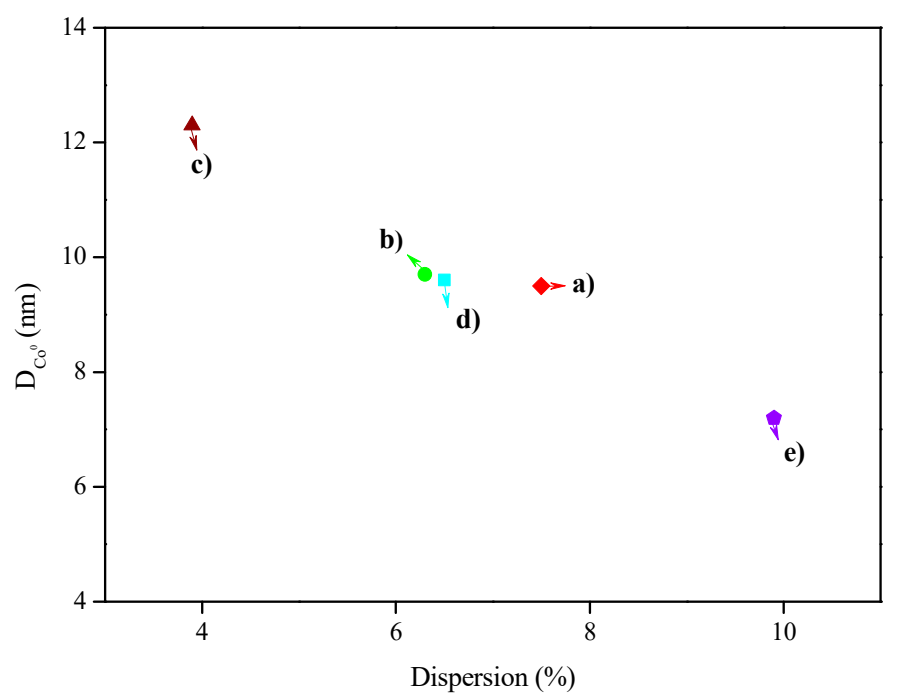

Figure 6. Comparison between $\mathrm{Co}^{0}$ crystallites size and Dispersion over the SBA-15 material used as support for (a) Co/SBA-15; (b) Co-Cu/SBA-15; (c) Co-Ag/SBA-15; (d) Co-Ce/SBA-15; (e) Co-Cr/SBA-15.

\subsection{Catalytic Tests}

AASR (acetic acid steam reforming) reactions were carried out after the reduction of the catalysts. All experiments were performed using an aqueous solution of acetic acid with a $\mathrm{S} / \mathrm{C}$ molar ratio $=2$ and a WHSV $=30.1 \mathrm{~h}^{-1}$ at atmospheric pressure and $600{ }^{\circ} \mathrm{C}$ using $\mathrm{N}_{2}$ as carrier gas. Conversion data are not shown because all catalysts reached complete conversion along $5 \mathrm{~h}$ of time-on-stream, which implies high activity for all the samples in acetic acid conversion at these reaction conditions. However, different product distributions were achieved indicating different activities in acetic acid steam reforming reaction, ascribed to the role of a second metal in secondary reactions. In this sense, hydrogen and carbon co-products distribution (dry basis) are displayed in Figure 7.

The $\mathrm{H}_{2}$ content expected at equilibrium at the experimental conditions, predicted by means of the software GasEQ, based on the method of free Gibbs energy minimization, is also shown. Regarding products distribution, all catalysts reached high hydrogen concentration, above 53\%. As known, Co-based catalysts allow the breaking of C-C bonds (only methane is produced as hydrogen-containing product) but also of C-H bonds [22]. Moreover, an effective catalyst must also be active in WGS reaction in order to eliminate $\mathrm{CO}$ from the metal surface during steam reforming. Over $\mathrm{Co}$, methane 
reforming and WGS activity was presented and this clearly shown by products formation. Among them, $\mathrm{CO}_{2}$ formation is highest and followed by $\mathrm{CO}, \mathrm{CH}_{4}$, thus WGS is more pronounced compared to other disproportionation and decomposition reactions. $\mathrm{Cu}, \mathrm{Ag}$ and $\mathrm{Ce}$ addition to Co/SBA-15 decreases the hydrogen content in the gas outlet stream in line with higher co-carbon products percentages. In contrast, $\mathrm{Co}-\mathrm{Cr} / \mathrm{SBA}-15$ reached the highest hydrogen concentration in the product stream. This behavior is related to the small Co crystallite size (see Table 1) leading to higher active sites surface area $[59,60]$. Therefore, $\mathrm{Cr}$ addition improved the catalytic performance by preventing Co agglomeration. In fact, Casanovas et al. [40] have published similar behavior adding $\mathrm{Cr}$ to $\mathrm{Co} / \mathrm{ZnO}$ being more active and selective for ethanol steam reforming. On the other side, Co-Ag/SBA-15 achieved the lowest hydrogen concentration and therefore carbon containing products composition was higher, probably due to the pore blocking effect and the highest $\mathrm{Co}$ crystallite size. Co-Cu/SBA-15 and $\mathrm{Co}-\mathrm{Ce} / \mathrm{SBA}-15$ showed higher $\mathrm{CO}_{2} / \mathrm{CO}$ molar ratio compared to the other samples (3/2) suggesting that the activity for WGS reaction was increased [60]. If WGS reaction is favored, an increase in the hydrogen production is expected but the hydrogen content reached with these two catalysts was lower than with $\mathrm{Co} / \mathrm{SBA}-15\left(\mathrm{CO}_{2} / \mathrm{CO}\right.$ ratio $\left.=1.7\right)$ thus, it is possible to assume that the presence of a second metal hinders reactants access to $\mathrm{Co}$ active centers, thereby avoiding their catalytic role breaking $\mathrm{C}-\mathrm{H}$ bonds. Finally, Co-Cu/SBA-15, Co-Ag/SBA-15 and Co-Ce/SBA-15 showed an increase of $\mathrm{CH}_{4}$ from $2 \%$ to almost $5 \%$ in comparison to the Co/SBA-15 sample. $\mathrm{CH}_{4}$ formation can be due to the decomposition of acetic acid or methanation [61]. Particularly, $\mathrm{Co}-\mathrm{Cu} / \mathrm{SBA}-15$ and $\mathrm{Co}-\mathrm{Ce} / \mathrm{SBA}-15$ produce more $\mathrm{CH}_{4}$ in line with the reduction of $\mathrm{H}_{2}$ and $\mathrm{CO}$ content which indicates that $\mathrm{Cu}$ and $\mathrm{Ce}$ promote the methanation reaction $\left(3 \mathrm{H}_{2}+\mathrm{CO} \rightarrow \mathrm{CH}_{4}+\mathrm{H}_{2} \mathrm{O}\right)$ [62]. Instead, the increase of produced methane with Co-Ag/SBA-15 could be due to the decomposition of acetic acid since the $\mathrm{CO}$ content was kept constant while both $\mathrm{CO}_{2}$ and $\mathrm{CH}_{4}$ concentrations increase, which would be in accordance with the stoichiometry of the reaction $\mathrm{CH}_{3} \mathrm{COOH} \rightarrow \mathrm{CH}_{4}+\mathrm{CO}_{2}$. However, other parallel and consecutive reactions varying the $\mathrm{CO}$, $\mathrm{CO}_{2}$ and $\mathrm{CH}_{4}$ content can be taking place.

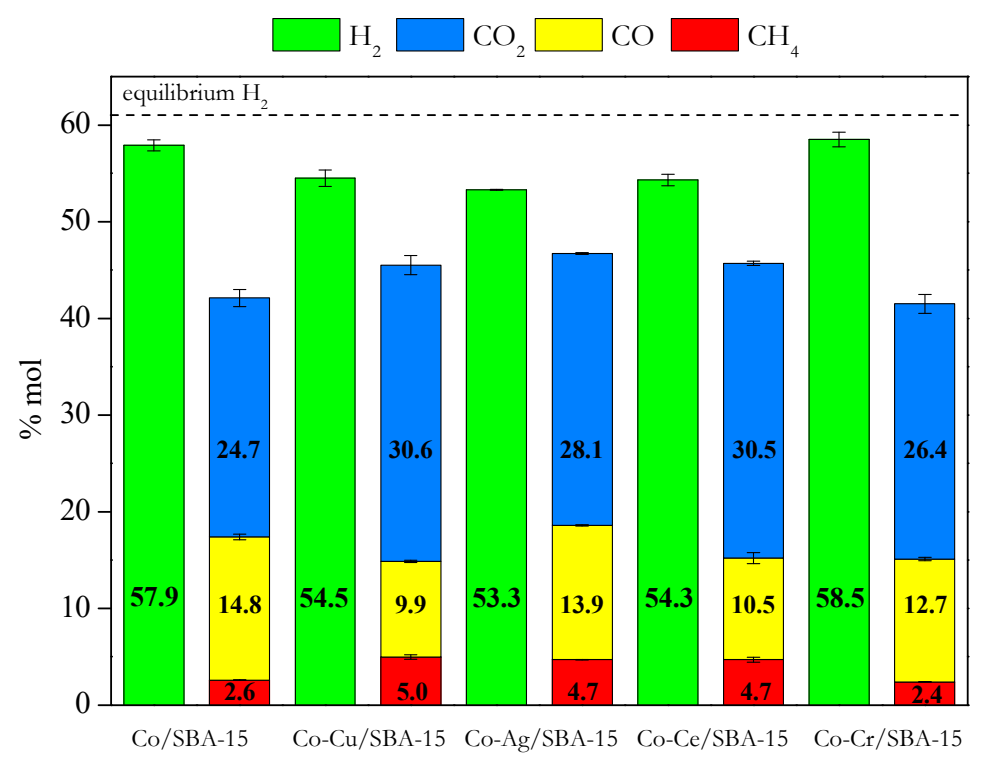

Figure 7. Products distribution in outlet gas stream produced in the acetic acid steam reforming over Co-M/SBA-15 (M: Cu, Ag, Ce, Cr) catalysts at T $=600{ }^{\circ} \mathrm{C}, \mathrm{P}=1 \mathrm{~atm}$, time-on-stream $=5 \mathrm{~h}$.

Regarding the evolution of $\mathrm{H}_{2}$ selectivity, calculated as the ratio between hydrogen produced and 4 times the reacted acetic acid (stoichiometry), with reaction time showed in Figure $8 \mathrm{Co}-\mathrm{Cu} / \mathrm{SBA}-15$ and Co-Ag/SBA-15 samples exhibited a decrease at $2 \mathrm{~h}$ but after that, it remains almost constant. Regardless, the $\mathrm{H}_{2}$ selectivity of the rest of catalysts remains almost unaltered with time-on-stream. Therefore, no deactivation was detected for Co/SBA-15, Co-Ce/SBA-15 and Co-Cr/SBA-15 samples. 
In addition, it can be assessed that $\mathrm{Co}-\mathrm{Cr} / \mathrm{SBA}-15$ sample also achieved the highest $\mathrm{H}_{2}$ selectivity close to the thermodynamic value at the present reaction conditions. This result is promising compared to those obtained by Ni-based catalysts widely referenced in literature for acetic acid steam reforming reactions. In this sense, Thaicharoensutcharittham et al. [63] reported that $\mathrm{Ni} / \mathrm{Ce}_{0.75} \mathrm{Zr}_{0.25} \mathrm{O}_{2}$ catalyst with a Ni loading of $5 \mathrm{wt} . \%$ reached hydrogen selectivity of $33.54 \mathrm{~mol} \%$ with a S/C $=1, \mathrm{n}$ using a S/C $=3$. On the other hand, Wang et al. [64] achieved hydrogen selectivity between 54.5 and $70.9 \mathrm{~mol}$ $\%$ for reaction tests carried out at $550{ }^{\circ} \mathrm{C}$ and $650{ }^{\circ} \mathrm{C}$ respectively, with $\mathrm{S} / \mathrm{C}=3$ using Ni/Attapulgite catalysts. In another work, Nogueira et al. [65] published the catalytic performance of Ni catalysts supported on (MgO)-modified $\gamma-\mathrm{Al}_{2} \mathrm{O}_{3}$ reaching, a $\mathrm{H}_{2}$ selectivity of $67.5 \mathrm{~mol} \%$ at higher $\mathrm{S} / \mathrm{C}$ ratio $(\mathrm{S} / \mathrm{C}=4)$. Additionally, our group tested at similar operation conditions $\left(600{ }^{\circ} \mathrm{C}, \mathrm{GHSV}: 11000 \mathrm{~h}^{-1}\right)$ Ni-based catalysts in AASR with a S/C $=4$ [38]. In that work, we achieved up to $60 \mathrm{~mol} \%$ of hydrogen content for both Ni/SBA-15 and Ni-Cr/SBA-15, which implied $\mathrm{H}_{2}$ selectivities between 56.6-59.9 mol \%. These values are lower than those achieved with Co-M/SBA-15 catalysts in the present work, even though lower $\mathrm{S} / \mathrm{C}$ ratio has been used that should lead to worse catalytic results. Despite differences in reaction conditions, mainly $\mathrm{S} / \mathrm{C}$ molar ratio, these $\mathrm{H}_{2}$ selectivity values are lower than that achieved by Co-Cr/SBA-15 sample. Furthermore, we also observed the beneficial effect of adding $\mathrm{Cr}$ to catalysts in our recently published works [38,43], where we reached using $\mathrm{Cr}$ as promoter added to Ni/SBA-15 catalysts, better catalytic performance using different feedstock in steam reforming reaction.

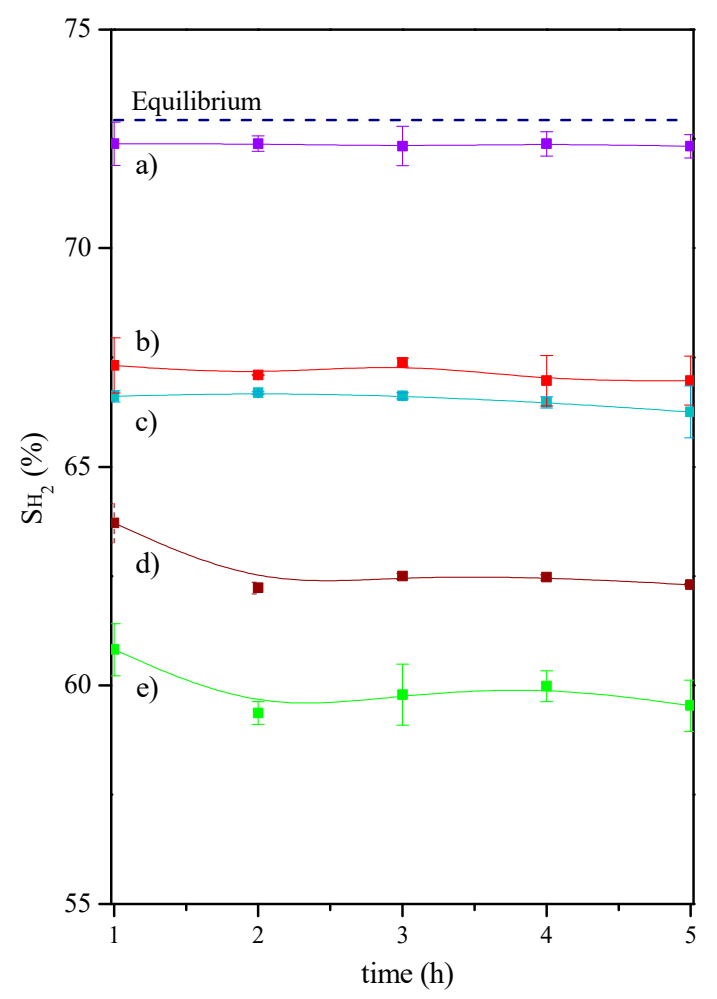

Figure 8. Hydrogen selectivity of gas stream produced in the acetic acid steam reforming over (a) Co-Cr/SBA-15; (b) Co/SBA-15; (c) Co-Ce/SBA-15; (d) Co-Ag/SBA-15; (e) Co-Cu/SBA-15 catalysts at $\mathrm{T}=600{ }^{\circ} \mathrm{C}, \mathrm{P}=1 \mathrm{~atm}$.

Coke formation during steam reforming has been reported as the main cause of SR catalyst deactivation [36]. It must be emphasized that catalyst deactivation is not only related to the amount of coke, but also to the nature of the coke formed, the morphology and the location over the catalyst structure [66]. In this sense, XRD patterns of used catalysts after $5 \mathrm{~h}$ (TOS) are shown in Figure 9. 


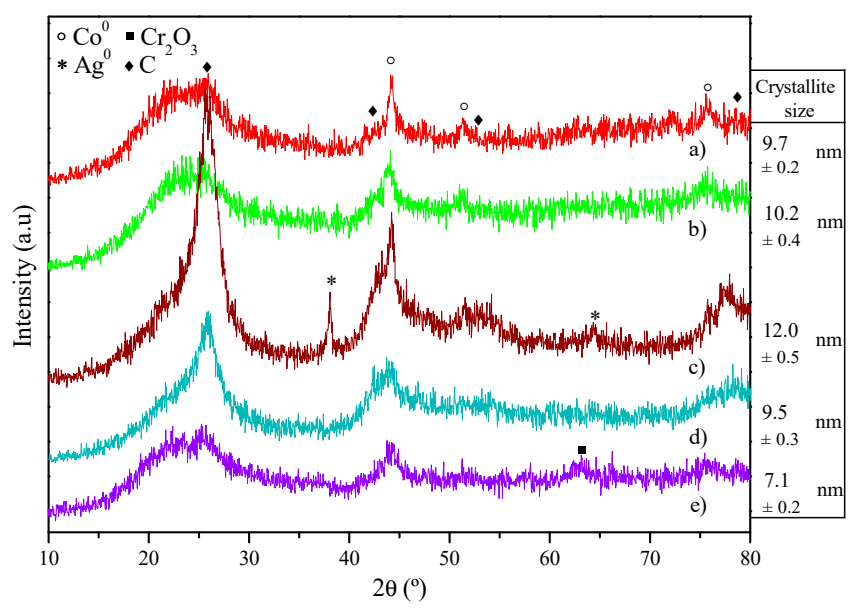

Figure 9. XRD patterns of used (a) Co/SBA-15; (b) Co-Cu/SBA-15; (c) Co-Ag/SBA-15; (d) Co-Ce/SBA-15; (e) Co-Cr/SBA-15 catalysts. $\mathrm{Co}^{0}$ crystallites sizes calculated from the (111) diffraction plane using Scherrer equation are displayed on the right.

Peaks corresponding to cubic $\mathrm{Co}^{0}$ (JCDPS 00001 1259) at $2 \theta=44.4^{\circ}, 51.3^{\circ}$ and $75.4^{\circ}$ can be still distinguished. In contrast to reduced samples (Figure 5), reflection peaks corresponding to graphitic carbon (JCDPS 00-041-1487) at $2 \theta=26.5^{\circ}, 42.6^{\circ}, 53.9^{\circ}$ and $78.8^{\circ}$ ascribed to (002), (100), (004) and (006) reflection planes, respectively, appear as a consequence of the coke deposition along the acetic acid steam reforming being more pronounced in Co-Ag/SBA-15 sample. Cobalt crystallites sizes of used catalysts (calculated from Scherrer equation) are shown on the right side of Figure 9. Comparing these results with those found in reduced samples (Table 1), it can be concluded that cobalt crystallites sizes were very similar, which indicates no significant sintering throughout the reforming reaction.

TGA can be used for the identification of the type of coke formed during the reaction since more ordered coke will need higher temperature to be oxidized [67]. It is normally reported that amorphous carbon is more reactive than graphitic in reactions with $\mathrm{O}_{2}$ [68] because it oxidizes at low temperatures whereas filamentous or graphitic carbon does at higher temperatures [69-71]. Figure 10 displays the derivative thermogravimetric (DTG) curves of the used catalysts along with the amount of coke formed during the reaction in terms of $\mathrm{mg}_{\mathrm{coke}} \cdot \mathrm{g}_{\mathrm{cat}}{ }^{-1} \cdot \mathrm{h}^{-1}$.

There are significant differences in the total coke content, in the order Co-Ag/SBA-15 > Co-Ce/SBA-15 $>\mathrm{Co}-\mathrm{Cu} / \mathrm{SBA}-15>\mathrm{Co} / \mathrm{SBA}-15>\mathrm{Co}-\mathrm{Cr} / \mathrm{SBA}-15$ which follows the reverse order of the hydrogen content in the outlet stream during AASR (see Figure 6). In general, all DTG profiles show a maximum around $500^{\circ} \mathrm{C}$ and a shoulder around $550{ }^{\circ} \mathrm{C}$, indicating the formation of some kind of carbon nanofibers with different ordering degree $[69,70]$. Co-Ag/SBA-15 showed a maximum around $441{ }^{\circ} \mathrm{C}$ which can be related to the formation of some defective carbon deposits. Co-Ag/SBA-15 obtained the worst catalytic results (high $\mathrm{CH}_{4}$ concentration and the lowest $\mathrm{H}_{2}$ concentration), in line with the highest carbon deposition. Besides, it is noteworthy that $\mathrm{Co}-\mathrm{Cr} / \mathrm{SBA}-15$ reduced the coke production two times compared to Co/SBA-15. It is known that $\mathrm{Cr}_{2} \mathrm{O}_{3}$ has been used as an oxide catalyst with outstanding carbon deposition resistance properties [72,73]. In our case, the reduction in carbon deposition can be also ascribed to the role of chromium avoiding the formation of large Co crystallites as it could be observed by TEM and measured by the Scherrer equation, because smaller Co crystallites will prevent the initiation of carbon nucleation leading to coke formation [74]. On the other hand, $\mathrm{Cr}_{2} \mathrm{O}_{3}$ has catalytic activity in the WGS reaction, lowering the $\mathrm{CO}$ concentration into the gas phase surrounding the catalytic bed, thus favoring the formation of $\mathrm{H}_{2}$ and $\mathrm{CO}_{2}$ [75]. In this sense, the extent Boudouard reaction $\left(2 \mathrm{CO}(\mathrm{g}) \rightarrow \mathrm{CO}_{2}(\mathrm{~g})+\mathrm{C}(\mathrm{s})\right)$, which is one of the main routes for coking, will be reduced.

Used catalysts were also analyzed by TEM as shown in Figure 11. In all cases, carbon nanofibers with different ordering degree can be observed. Besides, Co-Ag/SBA-15 micrograph shows some zones of defective coke deposits, in concordance with DTG results. 


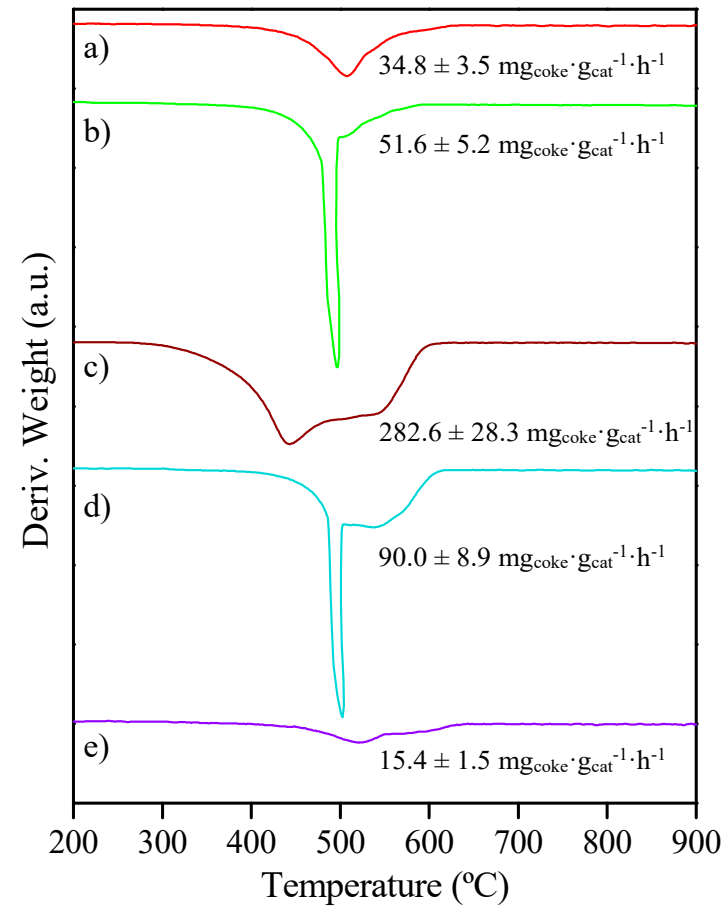

Figure 10. DTG curves of used (a) Co/SBA-15; (b) Co-Cu/SBA-15; (c) Co-Ag/SBA-15; (d) Co-Ce/SBA-15; (e) Co-Cr/SBA-15 samples after $5 \mathrm{~h}$ time-on-stream.

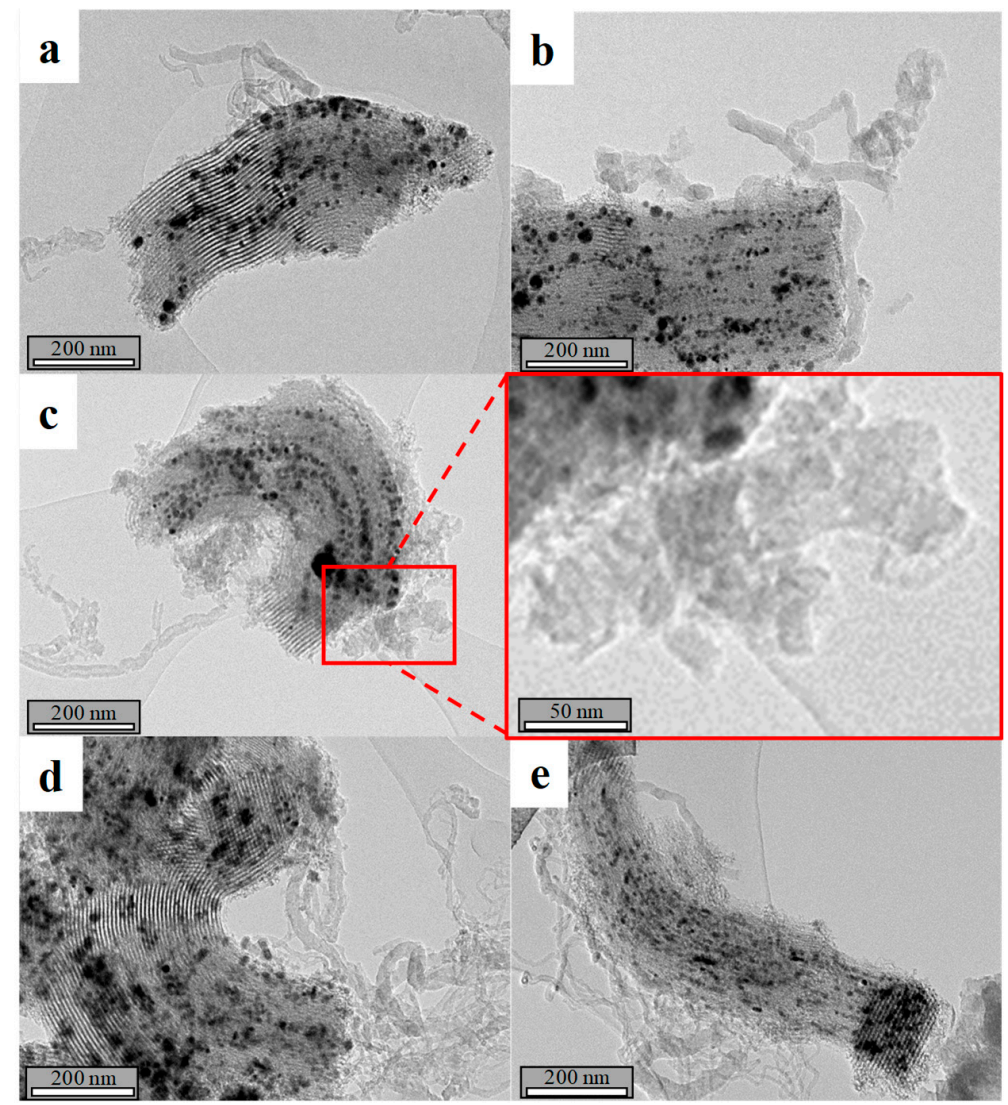

Figure 11. TEM micrographs of used (a): Co/SBA-15; (b): Co-Cu/SBA-15; (c): Co-Ag/SBA-15; (d): Co Ce/SBA 15; (e): Co-Cr/SBA-15 (5 h time-on-stream at $\left.600{ }^{\circ} \mathrm{C}\right)$. 
Finally, the Raman spectra of used catalysts in the range $1200-1700 \mathrm{~cm}^{-1}$ are presented in Figure 12. As it can be observed, two main bands appear in all cases, at 1330-1340 (D-band) and 1586-1591 cm-1 (G-band). G-band is ascribed to the stretching mode of carbon $\mathrm{sp}^{2}$ bonds of condensed graphitic aromatic structures such as graphite layer [76], whereas D-band is related to the carbon atoms vibration of disordered aromatic structures such as amorphous or defective filamentous carbon [70,77-79]. The presence of both bands exhibits the heterogeneity of carbon species constituting the coke formed during the AASR reaction. It has been reported that the intensity of the D band relative to the G band can be used as a qualitative measure of the formation of different kinds of carbon with different degree of graphitization or disorder in the carbon structure [78-80]. Smaller $\mathrm{I}_{\mathrm{D}} / \mathrm{I}_{\mathrm{G}}$ values indicate higher crystallinity due to higher contribution of the graphitic carbon structures formed [81,82] but it also implies more layers constituting the deposited carbon [83]. In these sense, the estimated values are summarized also in Figure 12. As can be seen, the $\mathrm{I}_{\mathrm{D}} / \mathrm{I}_{\mathrm{G}}$ ratio decreases in the following order: Co-Cr $/ \mathrm{SBA}-15\left(\mathrm{I}_{\mathrm{D}} / \mathrm{I}_{\mathrm{G}}=0.80\right)>\mathrm{Co} / \mathrm{SBA}-15\left(\mathrm{I}_{\mathrm{D}} / \mathrm{I}_{\mathrm{G}}=0.65\right)>\mathrm{Co}-\mathrm{Ce} / \mathrm{SBA}-15\left(\mathrm{I}_{\mathrm{D}} / \mathrm{I}_{\mathrm{G}}=0.61\right)>\mathrm{Co}-\mathrm{Ag} / \mathrm{SBA}-15$ $\left(\mathrm{I}_{\mathrm{D}} / \mathrm{I}_{\mathrm{G}}=0.53\right)>\mathrm{Co}-\mathrm{Cu} / \mathrm{SBA}-15\left(\mathrm{I}_{\mathrm{D}} / \mathrm{I}_{\mathrm{G}}=0.48\right)$. These results indicate that carbon deposition over the Co-Cu/SBA-15 sample occurs in larger extent on the Co surface when compared with the other samples, leading to the growth of well-ordered carbon, which may be responsible of catalyst deactivation since it act as a shell covering the active Co sites layer by layer [80]. It must be highlighted that the $\mathrm{H}_{2}$ selectivity represented in Figure 8, decreases in the same order as $\mathrm{I}_{\mathrm{D}} / \mathrm{I}_{\mathrm{G}}$ ratio. Therefore, the $\mathrm{H}_{2}$ selectivity is directly related to the kind of carbon deposited on the catalyst.

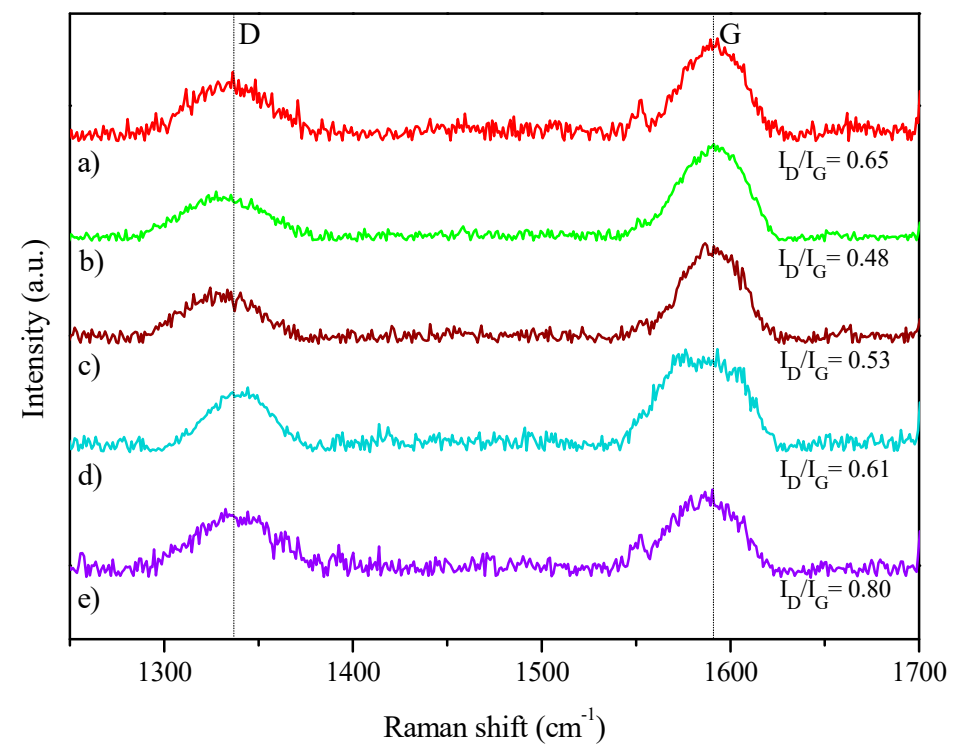

Figure 12. Raman spectra of used (a) Co/SBA-15; (b) Co-Cu/SBA-15; (c) Co-Ag/SBA-15; (d) Co-Ce/SBA-15; (e) Co-Cr/SBA-15 catalysts.

An AASR test done at long time-on-stream displayed in Figure 13 showed that Co-Cr/SBA-15 achieved good stability after $50 \mathrm{~h}$ time-on-stream. Conversion values were near $95 \%$ at the end of the reaction, while almost constant hydrogen selectivity ( $72 \mathrm{~mol} \%)$ was obtained. These results evidence that Co-Cr/SBA-15 sample is a promising option for acetic acid steam reforming, since hydrogen selectivity remains close to the equilibrium value for a long period and, in addition, this value is greater than those obtained with the Ni-based catalysts described in literature. 


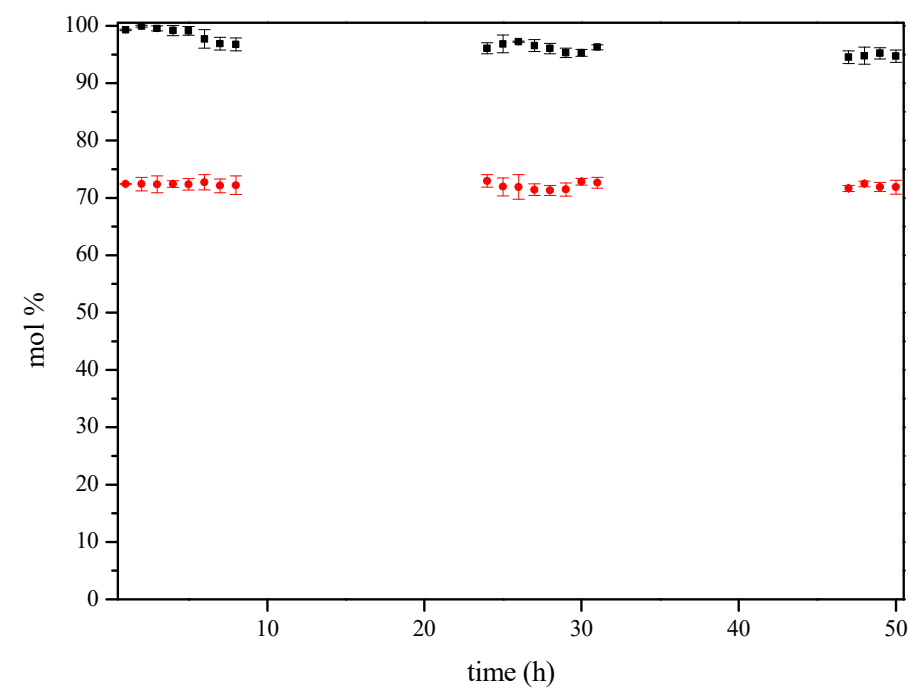

Figure 13. Acetic acid conversion ( $\square$ ) and hydrogen selectivity $(\bullet)$ during stability test of Co-Cr/SBA-15 catalyst at $\mathrm{T}=600^{\circ} \mathrm{C}, \mathrm{P}=1 \mathrm{~atm}$.

\section{Experimental Section}

\subsection{Catalysts Synthesis}

Mesostructured SBA-15 material, synthesized using the hydrothermal method described elsewhere [84], was used as catalysts support. Pluronic 123 and TEOS were used as surfactant and silica precursor (Aldrich, St. Louis, MO, USA) respectively.

Synthesis of Co-M/SBA-15 (M: Cu, Ag, Ce or Cr) catalysts was accomplished by the incipient wetness impregnation method described in previous work [85]. Metal loading was selected as $7 \mathrm{wt} . \%$ of $\mathrm{Co}$ and $2 \mathrm{wt} . \%$ of promoter [86]. In this way, mixed aqueous solutions of the corresponding nitrates were used for the co-impregnation: $\mathrm{Co}\left(\mathrm{NO}_{3}\right)_{2} \cdot 6 \mathrm{H}_{2} \mathrm{O}$ (Acros Organics, Morris Plains, NJ, USA) and $\mathrm{Cu}\left(\mathrm{NO}_{3}\right)_{2} \cdot 3 \mathrm{H}_{2} \mathrm{O}, \mathrm{Cr}\left(\mathrm{NO}_{3}\right)_{3} \cdot 9 \mathrm{H}_{2} \mathrm{O}, \mathrm{Ce}\left(\mathrm{NO}_{3}\right)_{3} \cdot 6 \mathrm{H}_{2} \mathrm{O}, \mathrm{AgNO}_{3}$ (Aldrich, St. Louis, $\mathrm{MO}, \mathrm{USA}$ ). Subsequently, the prepared samples were calcined under air at $550{ }^{\circ} \mathrm{C}$.

\subsection{Catalysts Characterization}

$\mathrm{N}_{2}$ adsorption/desorption at $77 \mathrm{~K}$ on a TRISTAR 3000 sorptometer (Micromeritics, Norcross, GA, USA) was used for the measurement of textural properties. Prior to the analysis samples were outgassed under vacuum at $200{ }^{\circ} \mathrm{C}$ for $4 \mathrm{~h}$. To determine the chemical composition of the catalysts, ICP-AES technique was used. The equipment was a VISTA-PRO AX CCD-Simultaneous ICP-AES spectrophotometer (Varian, Palo Alto, CA, USA). Samples were previously treated by acidic digestion. XRD measurements were recorded using an X'pert PRO diffractometer (Philips, Eindhoven, The Netherlands) using $\mathrm{Cu} \mathrm{K} \alpha$ radiation. The Scherrer equation was used to estimate the metal crystallites mean diameter. Reducibility of the samples was studied by TPR analyses. A Micromeritics (Norcross, GA, USA) AUTOCHEM 2910 system was used. The experiment is carried out flowing $35 \mathrm{~N} \mathrm{~mL} / \mathrm{min}$ of gas $\left(10 \% \mathrm{H}_{2} / \mathrm{Ar}\right)$ through the sample and increasing temperature up to $980{ }^{\circ} \mathrm{C}$ with a $5{ }^{\circ} \mathrm{C} / \mathrm{min}$ heating ramp. Samples were previously outgassed under Ar flow at $110{ }^{\circ} \mathrm{C}$ for $30 \mathrm{~min}$. Co dispersion of the catalysts was determined by hydrogen TPD in the same apparatus. For that, the samples were first reduced under $35 \mathrm{~N} \mathrm{~mL} / \mathrm{min}$ of gas $\left(10 \% \mathrm{H}_{2} / \mathrm{Ar}\right)$, then cooled to $50{ }^{\circ} \mathrm{C}$, and saturated with $\mathrm{H}_{2}$. After that, the physically absorbed $\mathrm{H}_{2}$ is removed by flushing $\mathrm{Ar}$ and finally heated up to $700{ }^{\circ} \mathrm{C}$ at $5{ }^{\circ} \mathrm{C} / \mathrm{min}$ in Ar flow $(30 \mathrm{~N} \mathrm{~mL} / \mathrm{min})$. TEM micrographs were obtained on a $200 \mathrm{kV}$ JEM 2100 microscope (JEOL, Tokyo, Japan), with a resolution of $0.25 \mathrm{~nm}$ at the National Centre for Electron Microscopy (CNME, Complutense University of Madrid, Madrid, Spain). It also has the possibility to achieve microanalysis results by energy dispersive X-ray spectroscopy (EDX). Samples preparation involve their suspension in acetone and subsequently deposition on a carbon-coated copper or nickel 
grid. Carbon deposited during catalytic tests was measured by thermogravimetric analysis (TGA), TEM and Raman spectroscopy. TGA analysis were performed in airflow with a heating rate of $5{ }^{\circ} \mathrm{C} / \mathrm{min}$ up to $1000^{\circ} \mathrm{C}$ on a SDT 2960 thermobalance (TA Instruments, New Castle, DE, USA). Raman spectra were recorded using a NRS-5000/7000 series Raman spectrometer (JASCO, Tokyo, Japan) at the IMDEA Energy Institute.

\subsection{Catalytic Tests}

Acetic acid steam reforming reactions were performed at $600{ }^{\circ} \mathrm{C}$ on a MICROACTIVITY-PRO unit (PID Eng. \& Tech. S.L., Alcobendas, Madrid, Spain) as described in previous works [7,38,85,87]. The reactor consists in a fixed-bed tubular reactor in stainless steel 316 (i.d. $=9.2 \mathrm{~mm}, \mathrm{~L}=300 \mathrm{~mm}$ ). The reactor is located inside an electric oven of low thermal, where temperature in the catalytic bed was measured by means of a K-thermocouple. All the components inside the hot box were maintained at $200{ }^{\circ} \mathrm{C}$ to prevent condensation in the pipes and to preheat the reactants. A schematic diagram is displayed in Figure 14.

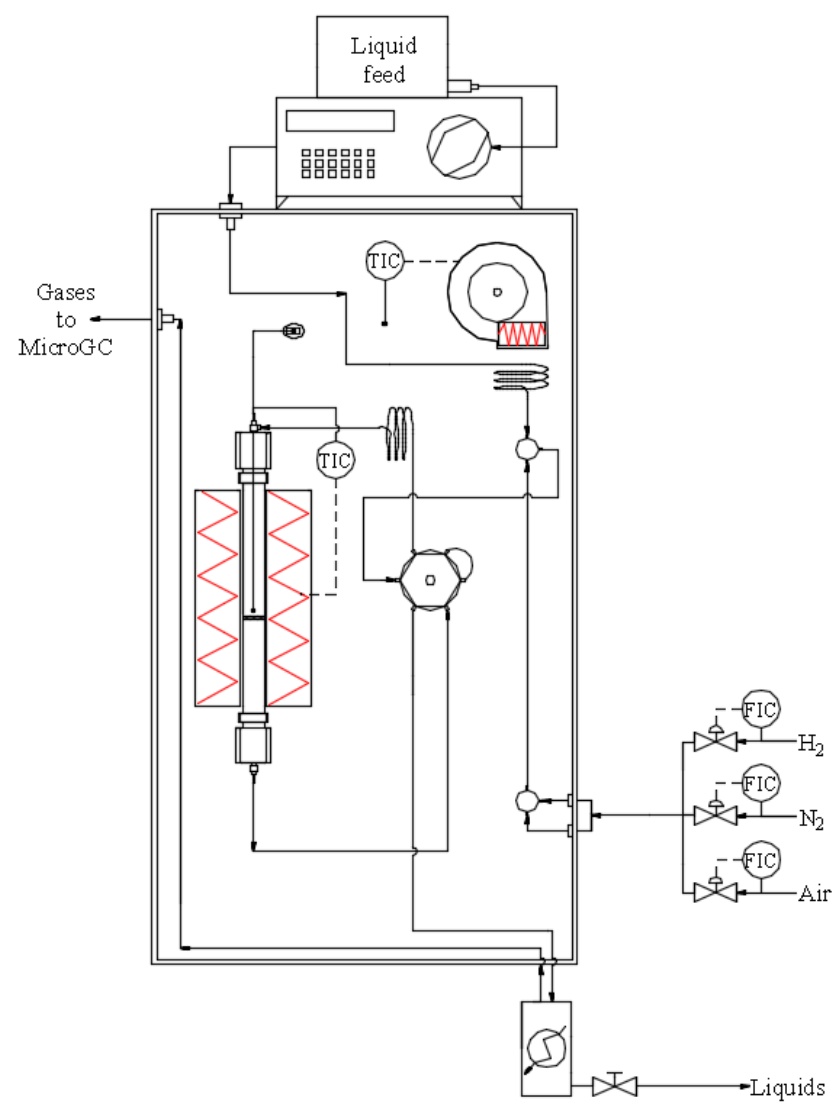

Figure 14. Schematic diagram of the catalytic testing setup [38].

The reactions were carried out isothermally at atmospheric pressure. Before tests, all catalysts were reduced under pure hydrogen $(30 \mathrm{~mL} / \mathrm{min})$ up to $700{ }^{\circ} \mathrm{C}$ with a heating rate of $2{ }^{\circ} \mathrm{C} / \mathrm{min}$. Temperature was maintained for $30 \mathrm{~min}$. Reaction feed was a mixture of acetic acid and water using a steam to carbon molar ratio of 2, using $\mathrm{N}_{2}$ as carrier and internal standard $\left(\mathrm{GHSV}=11,000 \mathrm{~h}^{-1}\right)$. The composition of the outlet gas was measured online with an 490 Micro-GC (Agilent, Santa Clara, CA, USA) equipped with a thermal conductivity detector (TCD), a PoraPlot U column $(10 \mathrm{~m})$ and a Molecular Sieve 5A column $(20 \mathrm{~m})$ using $\mathrm{He}$ and $\mathrm{Ar}$ as carrier gas, respectively. Condensable vapors were trapped in the condenser at $4{ }^{\circ} \mathrm{C}$ and analyzed in a Varian (Palo Alto, CA, USA) CP-3900 chromatograph equipped with a CP-WAX $52 \mathrm{CB}(30 \mathrm{~m} \times 0.25 \mathrm{~mm}, \mathrm{DF}=0.25)$ column and flame ionization detector (FID). 


\section{Conclusions}

The incorporation of a second metal like $\mathrm{Cu}, \mathrm{Ag}$, Ce or $\mathrm{Cr}$ into Co/SBA-15 sample catalyst resulted in bimetallic catalysts with very different properties and catalytic behavior in acetic acid steam reforming. Co-Ag/SBA-15 presented some pore blockage of the SBA-15 structure due to the presence of isolated silver oxide particles. $\mathrm{Cu}$ and $\mathrm{Ag}$ addition to Co/SBA-15 led to a significant decrease in the reduction temperature, as shown in $\mathrm{H}_{2}$-TPR profiles. $\mathrm{Cu}$ addition to $\mathrm{Co} / \mathrm{SBA}-15$ favors $\mathrm{Co}$ oxide reducibility, while maintaining almost unaltered $\mathrm{Co}^{0}$ crystallites size. In contrast, Co-Ag/SBA-15 showed also lower reduction temperatures but larger $\mathrm{Co}^{0}$ crystallites than Co/SBA-15. However, $\mathrm{Ce}$ addition does not affect significantly neither reducibility nor $\mathrm{Co}^{0}$ crystallite size. Finally, $\mathrm{Cr}$ addition to Co/SBA-15 strongly decreases Co crystallites size, induced by the presence of chromium oxides, improving metal dispersion with a slight decrease in the reduction temperature.

Regarding acetic acid steam reforming, Co-Cu/SBA-15 and Co-Ag/SBA-15 gave lower hydrogen selectivity than unmodified Co/SBA- 15 catalyst. However, $\mathrm{Cr}$ addition improved the catalytic behavior reaching the highest hydrogen selectivity next to the thermodynamic equilibrium. After the steam reforming tests, cobalt crystallites sizes in the used catalysts were very similar to those in fresh samples, indicating that coke deposition and not sintering is the cause of catalysts deactivation. Besides, the amount of coke formed on Co-Cr/SBA-15 was much lower than on the rest of the catalysts after $5 \mathrm{~h}$ of time on stream. Another difference resided in the nature of coke deposited because disordered aromatic structures such as amorphous or defective filamentous carbon were formed in a higher extent on Co-Cr/SBA-15 $\left(\mathrm{I}_{\mathrm{D}} / \mathrm{I}_{\mathrm{G}}=0.80\right)$ while the contribution of condensed graphitic aromatic structures increased in Co-Cu/SBA-15 $\left(\mathrm{I}_{\mathrm{D}} / \mathrm{I}_{\mathrm{G}}=0.48\right)$. Thus, $\mathrm{Cr}$ addition to Co/SBA-15 resulted in the best catalytic performance on acetic acid steam reforming, but $\mathrm{Cr}$ toxicity opens the way to the search for other metals providing similar catalytic properties.

Author Contributions: Conceptualization, A.C. and J.A.C.; methodology, A.J.V.; validation, A.J.V.; formal analysis, A.C.; investigation, P.J.M.; writing-original draft preparation, P.J.M.; writing—review and editing, A.C., J.A.C. and A.J.V.; supervision, A.C., J.A.C. and A.J.V.; project administration, A.C. and J.A.C.; funding acquisition, A.C. and J.A.C.

Funding: This research was funded by the Spanish Ministry of Economy and Competiveness (project ENE2017-83696-R) and the Regional Government of Madrid (project S2018/EMT-4344).

Acknowledgments: The authors acknowledge the IMDEA Energy Institute and the Complutense University of Madrid for the Raman and TEM analyses, respectively.

Conflicts of Interest: The authors declare no conflict of interest.

\section{References}

1. Dobosz, J.; Małecka, M.; Zawadzki, M. Hydrogen generation via ethanol steam reforming over Co/HAp catalysts. J. Energy Inst. 2018, 91, 411-423. [CrossRef]

2. Vizcaíno, A.J.; Carrero, A.; Calles, J.A. Hydrogen Production from Bioethanol; Nova Science Publishers: New York, NY, USA, 2012.

3. Agency, I.E. Hydrogen Production and Storage: R\&D Priorities and Gaps; IEA Publications: Paris, France, 2006.

4. Ruocco, C.; Palma, V.; Ricca, A. Kinetics of Oxidative Steam Reforming of Ethanol Over Bimetallic Catalysts Supported on $\mathrm{CeO}_{2}-\mathrm{SiO}_{2}$ : A Comparative Study. Top. Catal. 2019, 62, 467-478. [CrossRef]

5. He, L.; Parra, J.M.S.; Blekkan, E.A.; Chen, D. Towards efficient hydrogen production from glycerol by sorption enhanced steam reforming. Energy Environ. Sci. 2010, 3, 1046-1056. [CrossRef]

6. Wang, Y.; Wang, C.; Chen, M.; Tang, Z.; Yang, Z.; Hu, J.; Zhang, H. Hydrogen production from steam reforming ethanol over Ni/attapulgite catalysts - Part I: Effect of nickel content. Fuel Process. Technol. 2019, 192, 227-238. [CrossRef]

7. Carrero, A.; Vizcaíno, A.J.; Calles, J.A.; García-Moreno, L. Hydrogen production through glycerol steam reforming using Co catalysts supported on SBA-15 doped with Zr, Ce and La. J. Energy Chem. 2017, 26, 42-48. [CrossRef] 
8. Shayan, E.; Zare, V.; Mirzaee, I. Hydrogen production from biomass gasification; a theoretical comparison of using different gasification agents. Energy Convers. Manag. 2018, 159, 30-41. [CrossRef]

9. Turner, J.; Sverdrup, G.; Mann, M.K.; Maness, P.C.; Kroposki, B.; Ghirardi, M.; Blake, D. Renewable hydrogen production. Int. J. Energy Res. 2008, 32, 379-407. [CrossRef]

10. Zheng, J.-L.; Zhu, Y.-H.; Zhu, M.-Q.; Kang, K.; Sun, R.-C. A review of gasification of bio-oil for gas production. Sustain. Energy Fuels 2019, 3, 1600-1622. [CrossRef]

11. López Barreiro, D.; Prins, W.; Ronsse, F.; Brilman, W. Hydrothermal liquefaction (HTL) of microalgae for biofuel production: State of the art review and future prospects. Biomass Bioenergy 2013, 53, 113-127. [CrossRef]

12. Chen, W.-H.; Lin, B.-J.; Huang, M.-Y.; Chang, J.-S. Thermochemical conversion of microalgal biomass into biofuels: A review. Bioresour. Technol. 2015, 184, 314-327. [CrossRef]

13. Chiaramonti, D.; Prussi, M.; Buffi, M.; Rizzo, A.M.; Pari, L. Review and experimental study on pyrolysis and hydrothermal liquefaction of microalgae for biofuel production. Appl. Energy 2017, 185, 963-972. [CrossRef]

14. Guo, Y.; Yeh, T.; Song, W.; Xu, D.; Wang, S. A review of bio-oil production from hydrothermal liquefaction of algae. Renew. Sustain. Energy Rev. 2015, 48, 776-790. [CrossRef]

15. Jacobson, K.; Maheria, K.C.; Kumar Dalai, A. Bio-oil valorization: A review. Renew. Sustain. Energy Rev. 2013, 23, 91-106. [CrossRef]

16. Remón, J.; Broust, F.; Volle, G.; García, L.; Arauzo, J. Hydrogen production from pine and poplar bio-oils by catalytic steam reforming. Influence of the bio-oil composition on the process. Int. J. Hydrog. Energy 2015, 40, 5593-5608. [CrossRef]

17. Zhou, D.; Zhang, L.; Zhang, S.; Fu, H.; Chen, J. Hydrothermal Liquefaction of Macroalgae Enteromorpha prolifera to Bio-oil. Energy Fuels 2010, 24, 4054-4061. [CrossRef]

18. Yang, C.; Jia, L.; Chen, C.; Liu, G.; Fang, W. Bio-oil from hydro-liquefaction of Dunaliella salina over Ni/REHY catalyst. Bioresour. Technol. 2011, 102, 4580-4584. [CrossRef]

19. Jena, U.; Das, K.C. Comparative Evaluation of Thermochemical Liquefaction and Pyrolysis for Bio-Oil Production from Microalgae. Energy Fuels 2011, 25, 5472-5482. [CrossRef]

20. Maddi, B.; Panisko, E.; Wietsma, T.; Lemmon, T.; Swita, M.; Albrecht, K.; Howe, D. Quantitative characterization of the aqueous fraction from hydrothermal liquefaction of algae. Biomass Bioenergy 2016, 93, 122-130. [CrossRef]

21. Silva, J.M.; Soria, M.A.; Madeira, L.M. Challenges and strategies for optimization of glycerol steam reforming process. Renew. Sustain. Energy Rev. 2015, 42, 1187-1213. [CrossRef]

22. $\mathrm{Hu}, \mathrm{X}$; $\mathrm{Lu}, \mathrm{G}$. Comparative study of alumina-supported transition metal catalysts for hydrogen generation by steam reforming of acetic acid. Appl. Catal. B Environ. 2010, 99, 289-297. [CrossRef]

23. Banach, B.; Machocki, A.; Rybak, P.; Denis, A.; Grzegorczyk, W.; Gac, W. Selective production of hydrogen by steam reforming of bio-ethanol. Catal. Today 2011, 176, 28-35. [CrossRef]

24. Ishihara, A.; Andou, A.; Hashimoto, T.; Nasu, H. Steam reforming of ethanol using novel carbon-oxide composite-supported Ni, Co and Fe catalysts. Fuel Process. Technol. 2020, 197, 106203. [CrossRef]

25. Khodakov, A.Y.; Chu, W.; Fongarland, P. Advances in the Development of Novel Cobalt Fischer-Tropsch Catalysts for Synthesis of Long-Chain Hydrocarbons and Clean Fuels. Chem. Rev. 2007, 107, 1692-1744. [CrossRef] [PubMed]

26. Llorca, J.; Dalmon, J.-A.; Ramírez de la Piscina, P.; Homs, N.S. In situ magnetic characterisation of supported cobalt catalysts under steam-reforming of ethanol. Appl. Catal. A Gen. 2003, 243, 261-269. [CrossRef]

27. Tsoncheva, T.; Ivanova, L.; Minchev, C.; Fröba, M. Cobalt-modified mesoporous $\mathrm{MgO}, \mathrm{ZrO}_{2}$, and $\mathrm{CeO}_{2}$ oxides as catalysts for methanol decomposition. J. Colloid Interface Sci. 2009, 333, 277-284. [CrossRef]

28. Calles, J.A.; Carrero, A.; Vizcaíno, A.J. Ce and La modification of mesoporous Cu-Ni/SBA-15 catalysts for hydrogen production through ethanol steam reforming. Microporous Mesoporous Mater. 2009, 119, $200-207$. [CrossRef]

29. Pereira, E.B.; Homs, N.; Martí, S.; Fierro, J.L.G.; Ramírez de la Piscina, P. Oxidative steam-reforming of ethanol over $\mathrm{Co} / \mathrm{SiO} 2, \mathrm{Co}-\mathrm{Rh} / \mathrm{SiO} 2$ and $\mathrm{Co}-\mathrm{Ru} / \mathrm{SiO} 2$ catalysts: Catalytic behavior and deactivation/regeneration processes. J. Catal. 2008, 257, 206-214. [CrossRef]

30. Chen, G.; Tao, J.; Liu, C.; Yan, B.; Li, W.; Li, X. Hydrogen production via acetic acid steam reforming: A critical review on catalysts. Renew. Sustain. Energy Rev. 2017, 79, 1091-1098. [CrossRef] 
31. Wang, Y.; Chen, M.; Yang, Z.; Liang, T.; Liu, S.; Zhou, Z.; Li, X. Bimetallic Ni-M (M=Co, Cu and Zn) supported on attapulgite as catalysts for hydrogen production from glycerol steam reforming. Appl. Catal. A Gen. 2018, 550, 214-227. [CrossRef]

32. Eschemann, T.O.; Oenema, J.; de Jong, K.P. Effects of noble metal promotion for $\mathrm{Co} / \mathrm{TiO}{ }_{2}$ Fischer-Tropsch catalysts. Catal. Today 2016, 261, 60-66. [CrossRef]

33. Jermwongratanachai, T.; Jacobs, G.; Ma, W.; Shafer, W.D.; Gnanamani, M.K.; Gao, P.; Kitiyanan, B.; Davis, B.H.; Klettlinger, J.L.S.; Yen, C.H.; et al. Fischer-Tropsch synthesis: Comparisons between Pt and Ag promoted $\mathrm{Co} / \mathrm{Al}_{2} \mathrm{O}_{3}$ catalysts for reducibility, local atomic structure, catalytic activity, and oxidation-reduction (OR) cycles. Appl. Catal. A Gen. 2013, 464-465, 165-180. [CrossRef]

34. Harun, N.; Abidin, S.Z.; Osazuwa, O.U.; Taufiq-Yap, Y.H.; Azizan, M.T. Hydrogen production from glycerol dry reforming over Ag-promoted $\mathrm{Ni} / \mathrm{Al}_{2} \mathrm{O}_{3}$. Int. J. Hydrog. Energy 2018. [CrossRef]

35. Konsolakis, M.; Sgourakis, M.; Carabineiro, S.A.C. Surface and redox properties of cobalt-ceria binary oxides: On the effect of Co content and pretreatment conditions. Appl. Surf. Sci. 2015, 341, 48-54. [CrossRef]

36. Trimm, D.L. Coke formation and minimisation during steam reforming reactions. Catal. Today 1997, 37, 233-238. [CrossRef]

37. Cerdá-Moreno, C.; Da Costa-Serra, J.F.; Chica, A. Co and La supported on Zn-Hydrotalcite-derived material as efficient catalyst for ethanol steam reforming. Int. J. Hydrog. Energy 2019, 44, 12685-12692. [CrossRef]

38. Calles, J.A.; Carrero, A.; Vizcaíno, A.J.; García-Moreno, L.; Megía, P.J. Steam Reforming of Model Bio-Oil Aqueous Fraction Using Ni-(Cu, Co, Cr)/SBA-15 Catalysts. Int. J. Mol. Sci. 2019, 20, 512. [CrossRef]

39. Casanovas, A.; Roig, M.; de Leitenburg, C.; Trovarelli, A.; Llorca, J. Ethanol steam reforming and water gas shift over $\mathrm{Co} / \mathrm{ZnO}$ catalytic honeycombs doped with $\mathrm{Fe}, \mathrm{Ni}, \mathrm{Cu}, \mathrm{Cr}$ and $\mathrm{Na}$. Int. J. Hydrog. Energy 2010, 35, 7690-7698. [CrossRef]

40. Casanovas, A.; de Leitenburg, C.; Trovarelli, A.; Llorca, J. Catalytic monoliths for ethanol steam reforming. Catal. Today 2008, 138, 187-192. [CrossRef]

41. Li, Z.; Si, M.; Li, X.; Lv, J. Effects of titanium silicalite and $\mathrm{TiO}_{2}$ nanocomposites on supported Co-based catalysts for Fischer-Tropsch synthesis. Appl. Organomet. Chem. 2019, 33, e4640. [CrossRef]

42. Tang, Y.; Yang, M.; Dong, W.; Tan, L.; Zhang, X.; Zhao, P.; Peng, C.; Wang, G. Temperature difference effect induced self-assembly method for Ag/SBA-15 nanostructures and their catalytic properties for epoxidation of styrene. Microporous Mesoporous Mater. 2015, 215, 199-205. [CrossRef]

43. Carrero, A.; Calles, J.A.; García-Moreno, L.; Vizcaíno, A.J. Production of Renewable Hydrogen from Glycerol Steam Reforming over Bimetallic Ni-(Cu,Co,Cr) Catalysts Supported on SBA-15 Silica. Catalysts 2017, 7, 55. [CrossRef]

44. Vizcaíno, A.J.; Carrero, A.; Calles, J.A. Hydrogen production by ethanol steam reforming over Cu-Ni supported catalysts. Int. J. Hydrog. Energy 2007, 32, 1450-1461. [CrossRef]

45. Sun, X.; Sun, L.; Wang, J.; Yan, Y.; Wang, M.; Xu, R. Confination of Ag nanostructures within SBA-15 by a "two solvents" reduction technique. J. Taiwan Inst. Chem. Eng. 2015, 57, 139-142. [CrossRef]

46. Martínez, A.; López, C.; Márquez, F.; Díaz, I. Fischer-Tropsch synthesis of hydrocarbons over mesoporous Co/SBA-15 catalysts: The influence of metal loading, cobalt precursor, and promoters. J. Catal. 2003, 220, 486-499. [CrossRef]

47. Fierro, G.; Lo Jacono, M.; Inversi, M.; Dragone, R.; Porta, P. TPR and XPS study of cobalt-copper mixed oxide catalysts: Evidence of a strong Co-Cu interaction. Top. Catal. 2000, 10, 39-48. [CrossRef]

48. Aspromonte, S.G.; Miró, E.E.; Boix, A.V. FTIR studies of butane, toluene and nitric oxide adsorption on Ag exchanged NaMordenite. Adsorption 2012, 18, 1-12. [CrossRef]

49. Lin, S.S.Y.; Kim, D.H.; Ha, S.Y. Metallic phases of cobalt-based catalysts in ethanol steam reforming: The effect of cerium oxide. Appl. Catal. A Gen. 2009, 355, 69-77. [CrossRef]

50. Yun, D.; Baek, J.; Choi, Y.; Kim, W.; Jong Lee, H.; Yi, J. Promotional Effect of Ni on a CrOx Catalyst Supported on Silica in the Oxidative Dehydrogenation of Propane with $\mathrm{CO}_{2}$. ChemCatChem 2012, 4. [CrossRef]

51. Chen, J.; Zhang, X.; Arandiyan, H.; Peng, Y.; Chang, H.; Li, J. Low temperature complete combustion of methane over cobalt chromium oxides catalysts. Catal. Today 2013, 201, 12-18. [CrossRef]

52. Zoican Loebick, C.; Lee, S.; Derrouiche, S.; Schwab, M.; Chen, Y.; Haller, G.L.; Pfefferle, L. A novel synthesis route for bimetallic CoCr-MCM-41 catalysts with higher metal loadings. Their application in the high yield, selective synthesis of Single-Wall Carbon Nanotubes. J. Catal. 2010, 271, 358-369. [CrossRef] 
53. Scheffe, J.R.; Steinfeld, A. Thermodynamic Analysis of Cerium-Based Oxides for Solar Thermochemical Fuel Production. Energy Fuels 2012, 26, 1928-1936. [CrossRef]

54. Amin, N.A.S.; Tan, E.F.; Manan, Z.A. SCR of $\mathrm{NO}_{\mathrm{x}}$ by $\mathrm{C}_{3} \mathrm{H}_{6}$ : Comparison between $\mathrm{Cu} / \mathrm{Cr} / \mathrm{CeO} 2$ and $\mathrm{Cu} / \mathrm{Ag} / \mathrm{CeO}_{2}$ catalysts. J. Catal. 2004, 222, 100-106. [CrossRef]

55. Cheng, W.-H.; Chen, I.; Liou, J.-S.; Lin, S.-S. Supported Cu Catalysts with Yttria-Doped Ceria for Steam Reforming of Methanol. Top. Catal. 2003, 22, 225-233. [CrossRef]

56. Huang, X.; Ma, L.; Wainwright, M.S. The influence of Cr, Zn and Co additives on the performance of skeletal copper catalysts for methanol synthesis and related reactions. Appl. Catal. A Gen. 2004, 257, 235-243. [CrossRef]

57. Wang, Z.; Xi, J.; Wang, W.; Lu, G. Selective production of hydrogen by partial oxidation of methanol over Cu/Cr catalysts. J. Mol. Catal. A Chem. 2003, 191, 123-134. [CrossRef]

58. Xu, L.; Duan, L.E.; Tang, M.; Liu, P.; Ma, X.; Zhang, Y.; Harris, H.G.; Fan, M. Catalytic $\mathrm{CO}_{2}$ reforming of $\mathrm{CH}_{4}$ over $\mathrm{Cr}$-promoted $\mathrm{Ni} / \mathrm{char}$ for $\mathrm{H}_{2}$ production. Int. J. Hydrog. Energy 2014, 39, 10141-10153. [CrossRef]

59. da Silva, A.L.M.; den Breejen, J.P.; Mattos, L.V.; Bitter, J.H.; de Jong, K.P.; Noronha, F.B. Cobalt particle size effects on catalytic performance for ethanol steam reforming-Smaller is better. J. Catal. 2014, 318, 67-74. [CrossRef]

60. Ma, H.; Zeng, L.; Tian, H.; Li, D.; Wang, X.; Li, X.; Gong, J. Efficient hydrogen production from ethanol steam reforming over La-modified ordered mesoporous Ni-based catalysts. Appl. Catal. B Environ. 2016, 181, 321-331. [CrossRef]

61. Hu, X.; Dong, D.; Shao, X.; Zhang, L.; Lu, G. Steam reforming of acetic acid over cobalt catalysts: Effects of $\mathrm{Zr}, \mathrm{Mg}$ and $\mathrm{K}$ addition. Int. J. Hydrog. Energy 2017, 42, 4793-4803. [CrossRef]

62. Biswas, P.; Kunzru, D. Steam reforming of ethanol on $\mathrm{Ni}-\mathrm{CeO}_{2}-\mathrm{ZrO}_{2}$ catalysts: Effect of doping with copper, cobalt and calcium. Catal. Lett. 2007, 118, 36-49. [CrossRef]

63. Thaicharoensutcharittham, S.; Meeyoo, V.; Kitiyanan, B.; Rangsunvigit, P.; Rirksomboon, T. Hydrogen production by steam reforming of acetic acid over Ni-based catalysts. Catal. Today 2011, 164, 257-261. [CrossRef]

64. Wang, Y.; Chen, M.; Liang, T.; Yang, Z.; Yang, J.; Liu, S. Hydrogen Generation from Catalytic Steam Reforming of Acetic Acid by Ni/Attapulgite Catalysts. Catalysts 2016, 6, 172. [CrossRef]

65. Nogueira, F.G.E.; Assaf, P.G.M.; Carvalho, H.W.P.; Assaf, E.M. Catalytic steam reforming of acetic acid as a model compound of bio-oil. Appl. Catal. B Environ. 2014, 160-161, 188-199. [CrossRef]

66. Valle, B.; Aramburu, B.; Benito, P.L.; Bilbao, J.; Gayubo, A.G. Biomass to hydrogen-rich gas via steam reforming of raw bio-oil over $\mathrm{Ni} / \mathrm{La}_{2} \mathrm{O}_{3}-\alpha \mathrm{Al}_{2} \mathrm{O}_{3}$ catalyst: Effect of space-time and steam-to-carbon ratio. Fuel 2018, 216, 445-455. [CrossRef]

67. Chen, J.; Yang, X.; Li, Y. Investigation on the structure and the oxidation activity of the solid carbon produced from catalytic decomposition of methane. Fuel 2010, 89, 943-948. [CrossRef]

68. Nagasawa, S.; Yudasaka, M.; Hirahara, K.; Ichihashi, T.; Iijima, S. Effect of oxidation on single-wall carbon nanotubes. Chem. Phys. Lett. 2000, 328, 374-380. [CrossRef]

69. Choong, C.K.S.; Zhong, Z.; Huang, L.; Wang, Z.; Ang, T.P.; Borgna, A.; Lin, J.; Hong, L.; Chen, L. Effect of calcium addition on catalytic ethanol steam reforming of $\mathrm{Ni} / \mathrm{Al}_{2} \mathrm{O}_{3}$ : I. Catalytic stability, electronic properties and coking mechanism. Appl. Catal. A Gen. 2011, 407, 145-154. [CrossRef]

70. Galetti, A.E.; Gomez, M.F.; Arrúa, L.A.; Abello, M.C. Hydrogen production by ethanol reforming over NiZnAl catalysts: Influence of Ce addition on carbon deposition. Appl. Catal. A Gen. 2008, 348, 94-102. [CrossRef]

71. Natesakhawat, S.; Watson, R.B.; Wang, X.; Ozkan, U.S. Deactivation characteristics of lanthanide-promoted sol-gel Ni/Al $\mathrm{Al}_{2} \mathrm{O}_{3}$ catalysts in propane steam reforming. J. Catal. 2005, 234, 496-508. [CrossRef]

72. Qi, W.; Chen, S.; Wu, Y.; Xie, K. A chromium oxide coated nickel/yttria stabilized zirconia electrode with a heterojunction interface for use in electrochemical methane reforming. RSC Adv. 2015, 5, 47599-47608. [CrossRef]

73. Garcia, L.A.; French, R.; Czernik, S.; Chornet, E. Catalytic steam reforming of bio-oils for the production of hydrogen: Effects of catalyst composition. Appl. Catal. A Gen. 2000, 201, 225-239. [CrossRef]

74. Helveg, S.; Sehested, J.; Rostrup-Nielsen, J.R. Whisker carbon in perspective. Catal. Today 2011, 178, 42-46. [CrossRef] 
75. Natesakhawat, S.; Wang, X.; Zhang, L.; Ozkan, U.S. Development of chromium-free iron-based catalysts for high-temperature water-gas shift reaction. J. Mol. Catal. A Chem. 2006, 260, 82-94. [CrossRef]

76. Sierra Gallego, G.; Mondragón, F.; Tatibouët, J.-M.; Barrault, J.; Batiot-Dupeyrat, C. Carbon dioxide reforming of methane over $\mathrm{La}_{2} \mathrm{NiO}_{4}$ as catalyst precursor-Characterization of carbon deposition. Catal. Today 2008, 133-135, 200-209. [CrossRef]

77. Carrero, A.; Calles, J.A.; Vizcaíno, A.J. Effect of $\mathrm{Mg}$ and Ca addition on coke deposition over Cu-Ni/SiO 2 catalysts for ethanol steam reforming. Chem. Eng. J. 2010, 163, 395-402. [CrossRef]

78. Montero, C.; Ochoa, A.; Castaño, P.; Bilbao, J.; Gayubo, A.G. Monitoring Ni0 and coke evolution during the deactivation of a Ni/La $\mathrm{La}_{3}-\alpha \mathrm{Al}_{2} \mathrm{O}_{3}$ catalyst in ethanol steam reforming in a fluidized bed. J. Catal. 2015, 331, 181-192. [CrossRef]

79. Osorio-Vargas, P.; Flores-González, N.A.; Navarro, R.M.; Fierro, J.L.G.; Campos, C.H.; Reyes, P. Improved stability of $\mathrm{Ni} / \mathrm{Al}_{2} \mathrm{O}_{3}$ catalysts by effect of promoters $\left(\mathrm{La}_{2} \mathrm{O}_{3}, \mathrm{CeO}_{2}\right)$ for ethanol steam-reforming reaction. Catal. Today 2016, 259, 27-38. [CrossRef]

80. Charisiou, N.D.; Siakavelas, G.; Papageridis, K.N.; Baklavaridis, A.; Tzounis, L.; Polychronopoulou, K.; Goula, M.A. Hydrogen production via the glycerol steam reforming reaction over nickel supported on alumina and lanthana-alumina catalysts. Int. J. Hydrog. Energy 2017, 42, 13039-13060. [CrossRef]

81. Silva, K.C.; Corio, P.; Santos, J.J. Characterization of the chemical interaction between single-walled carbon nanotubes and titanium dioxide nanoparticles by thermogravimetric analyses and resonance Raman spectroscopy. Vib. Spectrosc. 2016, 86, 103-108. [CrossRef]

82. Tzounis, L.; Kirsten, M.; Simon, F.; Mäder, E.; Stamm, M. The interphase microstructure and electrical properties of glass fibers covalently and non-covalently bonded with multiwall carbon nanotubes. Carbon 2014, 73, 310-324. [CrossRef]

83. Ferencz, Z.; Varga, E.; Puskás, R.; Kónya, Z.; Baán, K.; Oszkó, A.; Erdőhelyi, A. Reforming of ethanol on $\mathrm{Co} / \mathrm{Al}_{2} \mathrm{O}_{3}$ catalysts reduced at different temperatures. J. Catal. 2018, 358, 118-130. [CrossRef]

84. Zhao, D.; Feng, J.; Huo, Q.; Melosh, N.; Fredrickson, G.H.; Chmelka, B.F.; Stucky, G.D. Triblock copolymer syntheses of mesoporous silica with periodic 50 to 300 angstrom pores. Science 1998, 279, 548-552. [CrossRef] [PubMed]

85. Vizcaíno, A.J.; Carrero, A.; Calles, J.A. Ethanol steam reforming on Mg- and Ca-modified Cu-Ni/SBA-15 catalysts. Catal. Today 2009, 146, 63-70. [CrossRef]

86. Carrero, A.; Calles, J.A.; Vizcaíno, A.J. Hydrogen production by ethanol steam reforming over Cu-Ni/SBA-15 supported catalysts prepared by direct synthesis and impregnation. Appl. Catal. A Gen. 2007, 327, 82-94. [CrossRef]

87. Vizcaíno, A.J.; Carrero, A.; Calles, J.A. Comparison of ethanol steam reforming using Co and Ni catalysts supported on SBA-15 modified by Ca and Mg. Fuel Process. Technol. 2016, 146, 99-109. [CrossRef] 